$2-1, \beta_{2}=$

$\operatorname{crm} 6$

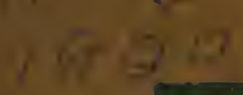

RI Mフ6 Musena
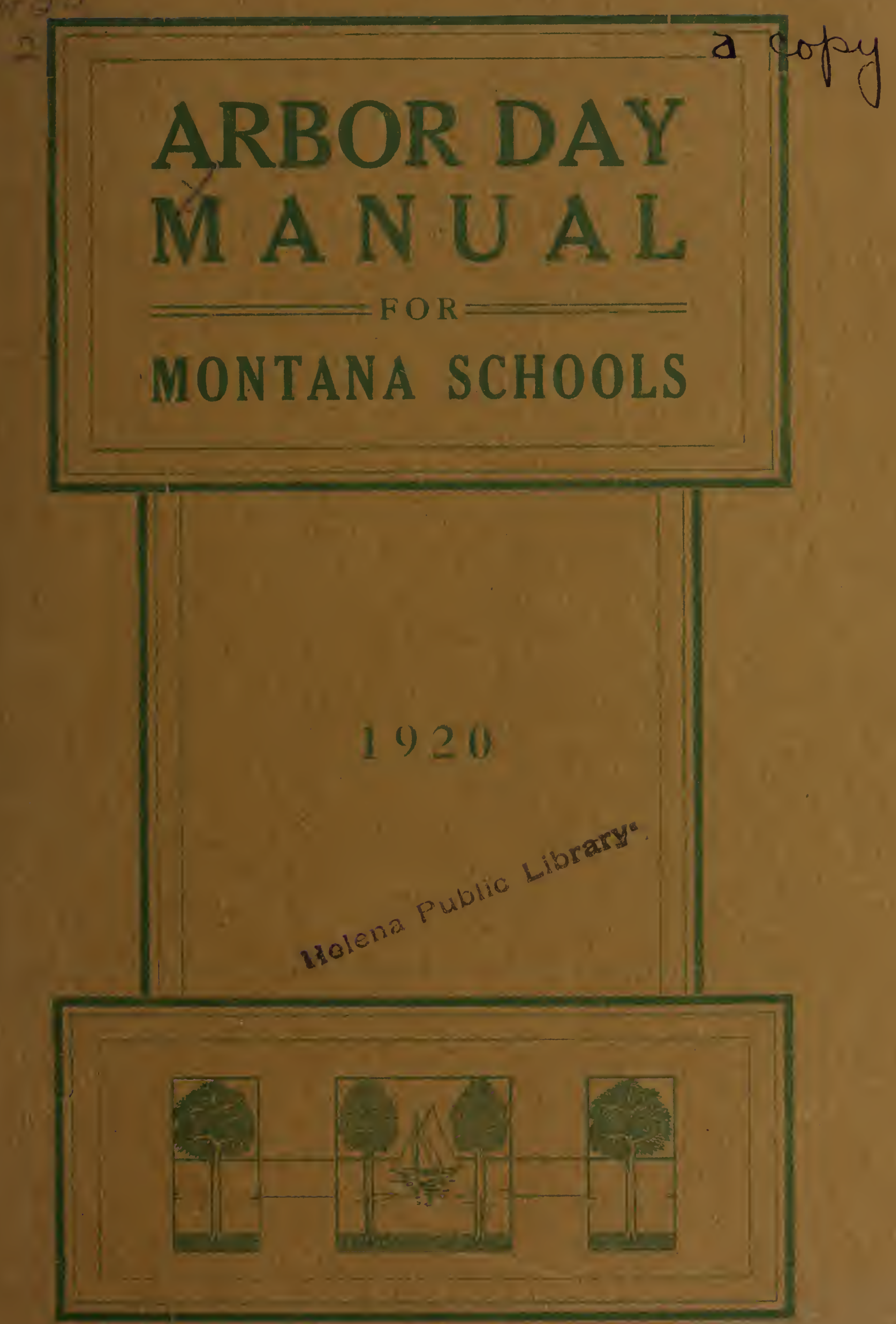


$$
\begin{aligned}
& -4=11
\end{aligned}
$$
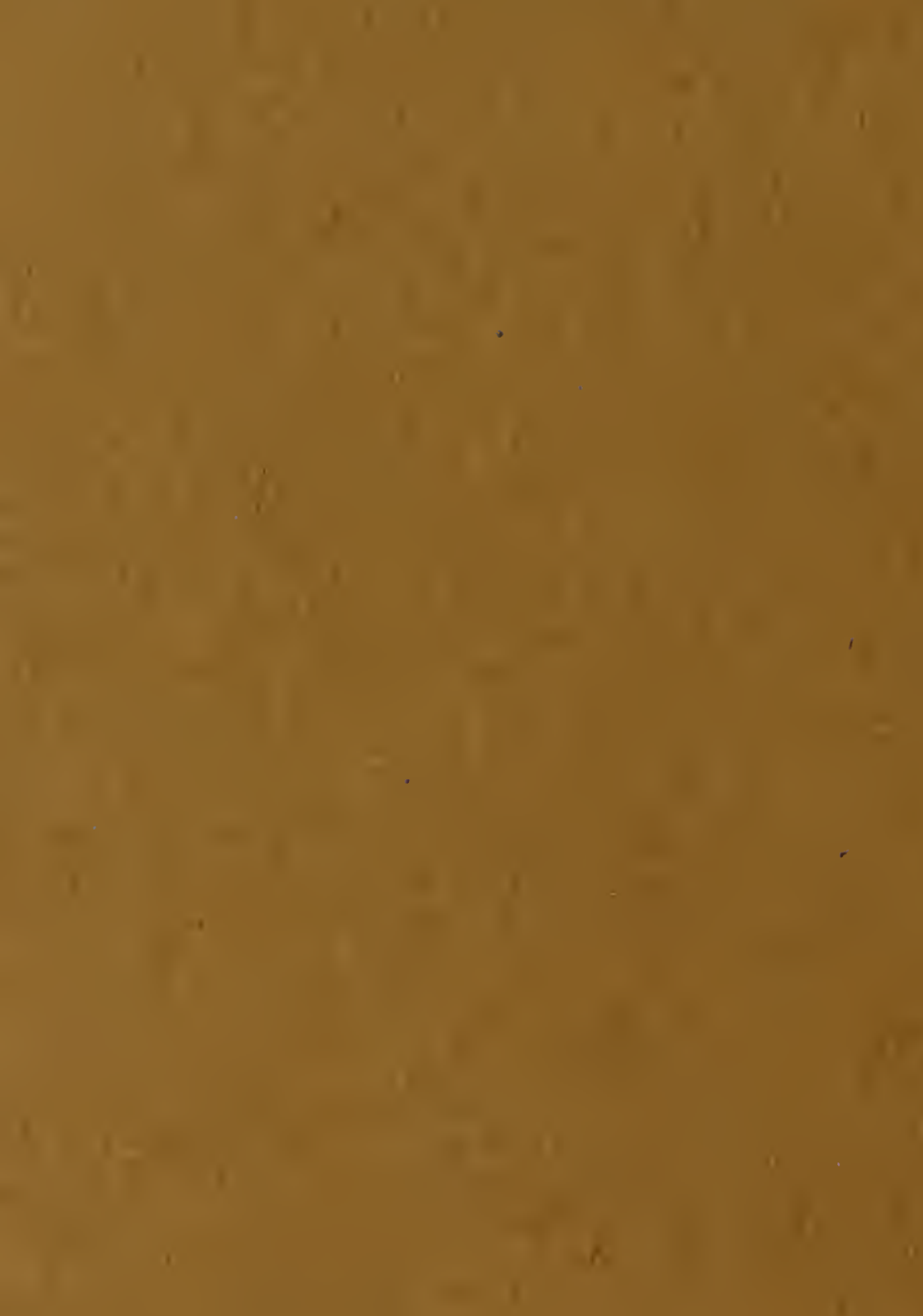

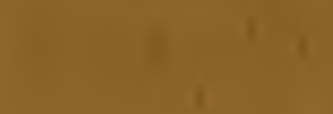
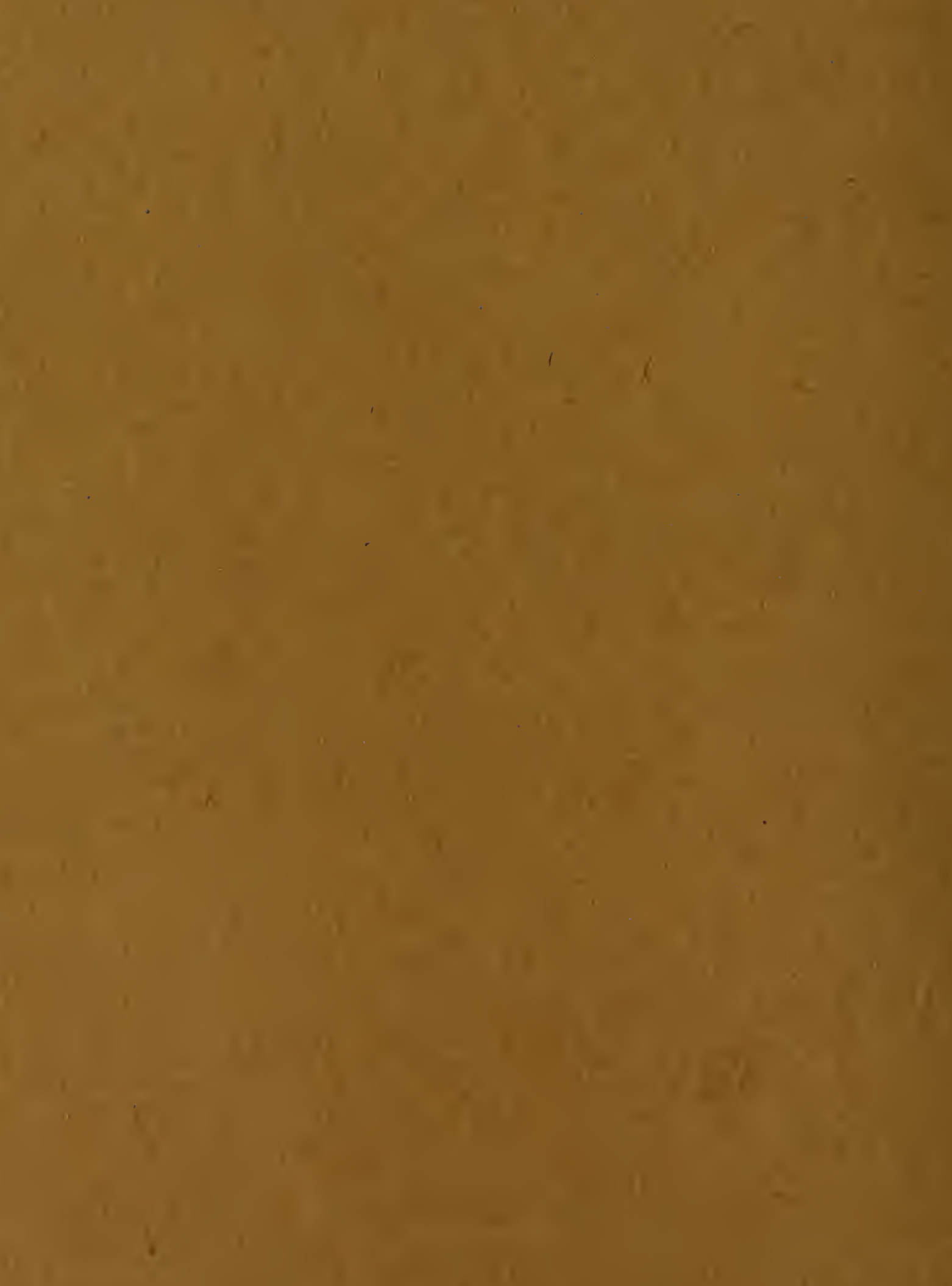


\section{Arbor Day Manual}

\section{Montana Schools}

Just why trees, flowers and shrubs will not grow on school grounds is truly something of an agricultural mystery. When land that raises eighty bushels of corn to the acre on one side of the fence refuses to nourish a bed of tulips or a few shrubs on the other side, we must, of force, conclude that something else, or the lack of something else, enters into the balance against the school yard.

-MABEL CARNEY.

\section{ISSUED BY}

\section{State Superintendent of Public Instruction} HELENA, MONTANA 


\section{PROPERTY OF SCHOOL DISTRICT}

NO.

MONTANA 


\section{FOREWORD}

One of the most important special days of the school year is Arbor Day, a day which teachers often find it difficult to have their schools fittingly observe. This manual is issued by the State Department of Public Instruction for the purpose of emphasizing the great importance which should be attached to the proper observance of the day and of calling attention to appropriate materials for such observances. Children in treeless parts of Montana should be enthused with a desire to plant trees and shrubs while those in wooded portions of the state should be inspired with an appreciation of trees which will insure their proper care and protection.

This manual should be carefully preserved as a part of the school library as only one copy for each school can be supplied. The amount of material contained in this manual should make it valuable for use for several years.

MAY TRUMPER, Superintendent of Public Instruction. 


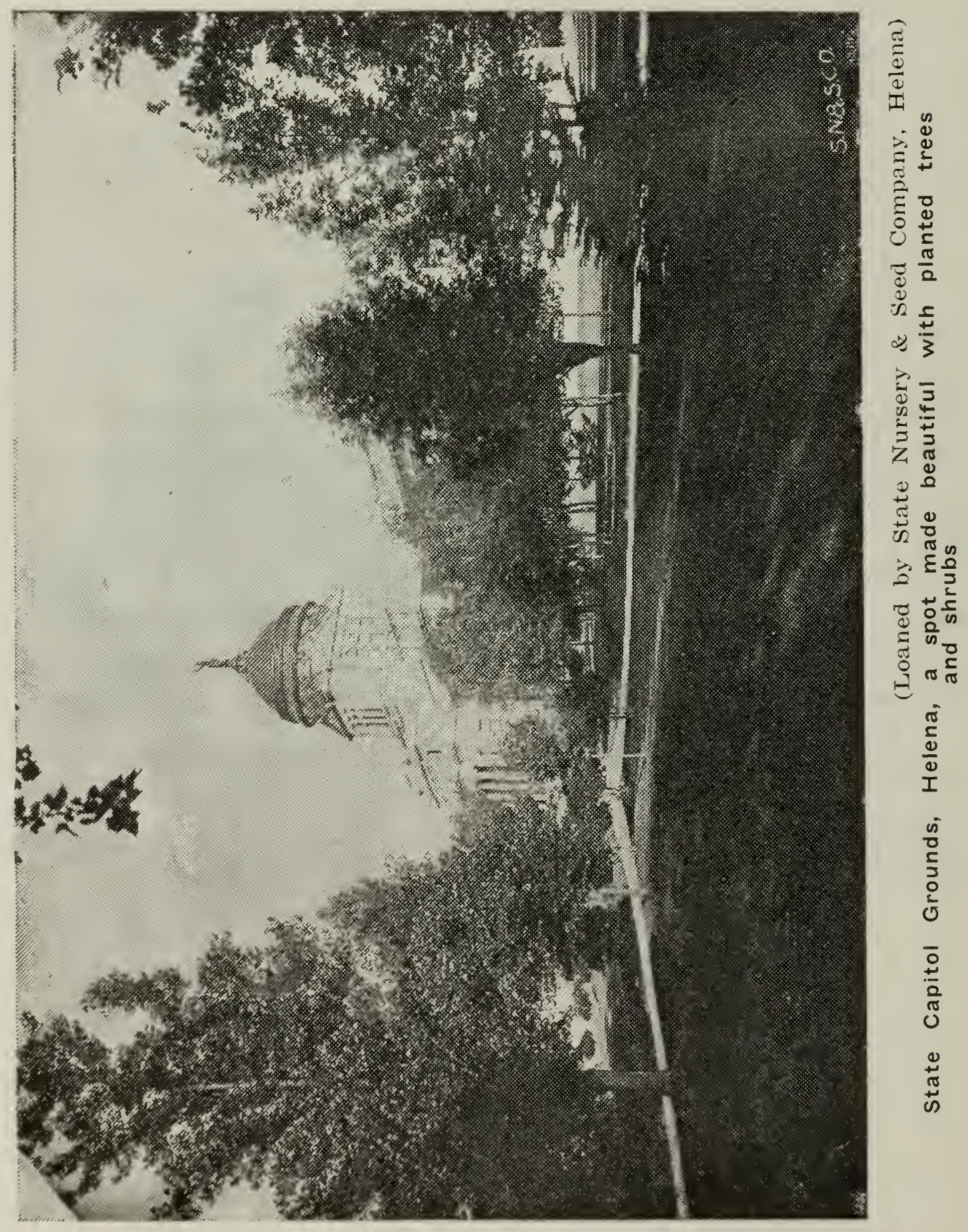




\section{ARBOR DAY LAW}

1. Date of.-The second Tuesday of May in each year shall be known throughout the State of Montana as Arbor Day.

2. Arbor Day Exercises.-In order that the children in our public schools shall assist in the work of adorning the school grounds with trees, and to stimulate the minds of the children toward the benefit of preservation and perpetuation of our forests and the growing timber it shall be the duty of the authorities in every public school district in the state to assemble the children in their charge on the above day in the school building or elsewhere, as they may deem proper, and to provide for and conduct under the general supervision of the city superintendent, county superintendent, teachers and trustees or other school authorities having the general charge and oversight of the public schools in each city or district, to have and hold such exercises as shall tend to encourage the planting, preservation and protection of trees and shrubs, and an acquaintance with the best methods to be adopted to accomplish such results.

3. Courses of Exercises.-The superintendent of public instruction shall have the power to prescribe from year to year a course of exercises and instruction in the subject hereinbefore mentioned, which shall be adopted and observed by the said public school authorities on Arbor Day. 


\section{HOW TO OBSERVE ARBOR DAY IN A VILLAGE OR RURAL SCHOOL}

In so far as is possible the day should be used to learn about trees. Plans should be made to have every lesson contribute something to the topic for the day. Such plans should interrupt the regular school work as little as possible. Tree quotations may be given in the morning exercises, and one or two songs sung. The reading lessons may be about trees. A number of tree poems and stories are found in the basal readers. Among them are the following:

Why the Evergreen Trees Keep Their Leaves.-Riverside Second Reader, p. 89.

The Fir Tree.-Riverside Third Reader, p. 68.

Swinging on a Birch Tree.-Riverside Fourth Reader, p. 172.

Also, in Easy Road to Reading, Second Reader, p. 77.

Under the Greenwood Tree.-Natural Method Fourth Reader, p. 307

The Little Pine Tree.-Natural Method First Reader, p. 65.

Why Do We Plant.-Henry Abbey.

Easy Road to Reading Fourth Reader, p. 70.

The Tree.-Bjornstjerne Bjornson.

Studies in Reading Fourth Reader, p. 137.

Woodman, Spare That Tree--George P. Morris.

EIson Grammar School Reader, Book I, p. 30.

Apple Blossoms.-William Wesley Martin.

Elson Grammar School Reader, Book II, p. $10 \mathrm{C}$.

The Planting of the Apple Tree.-William Cullen Bryart.

Elson Grammar School Reader, Book II, p. 296.

Young and Field Literary Readers, Book Six, p. 355.

If all reading lessons on trees have been read before Arbor Day, those selections may be referred to again by quotations or story telling in the language class. Compositions may be written or prepared for the special program of the afternoon.

The work in arithmetic might center around tree or lumber problems. On whatever topic in arithmetic children happen to be working, some problems regarding trees can easily be made. On Arbor Day trees may be planted, thereby adding to those already on the grounds. The number of trees needed to plant about the home, if planted at regular intervals, can be computed. The economic and commercial value of trees should be brought out. The worth of a grove of 400 trees can be estimated. Thomas' Rural Arithmetic, p. 
68, gives a number of good problems regarding fruit trees. Some of these might be used by upper grade children, adapting them to local conditions or making others similar to them.

Other subjects can be made to contribute their share to tree study. In geography some problems on forests might be taken up, such as, "What are the most important uses man has made of forest trees?" Out of the lesson should grow the need for conserving our forests and of preventing forest fires. Historic trees might be the topic for the history lesson and beautifying the streets and roadside with shade trees might be the topic for the civics lesson. A whole day of regular school work may thus be made to contribute to the study of trees and Arbor Day made meaningful to the children.

During the afternoon, however, it would be well to use an hour or more for special Arbor Day exercises followed by tree planting wherever that can be done. Unless the necessary care and attention can be given the young trees during the summer, it is not practical to plant trees. It is well known that in some parts of Montana it requires careful attention for several years to insure their growth. But the day should be observed, even tho it is not found feasible to plant trees. There can still be this concentration on tree study with appropriate exercises during a part of the afternoon.

\section{CELEBRATION OF ARBOR DAY}

Arbor Day was originally intended to benefit the treeless states of the West by stimulating the desire to plant trees for fuel, timber, shade, protection to buildings, orchards and crops, and for beauty. From there it spread to almost every state in the Union. The idea back of it is mostly an altruistic one, for the man who plants a tree cannot begin to keep the benefits derived from the growth of the tree to himself. Others will get the benefit of its shade, protection, perhaps its fruit, and its beauty. Furthermore, it was to interest the child in the study of trees as he watched the development of those planted by him. It opened a field for research and observation to him in which he could not help being interested. With the study of the tree and the care 
for it would come a love for it, and from this sprang the thot of making the day one entirely devoted to the whole field of nature, and not to trees alone. Again with the study of nature the natural resources of a country will be considered-their extent, value and use. Anything which tends to increase the benefits derived from these, or which contributes to the welfare of the people, is a patriotic work. So, finally, we have as the idea of Arbor Day, patriotism, because of the study and love of nature as manifested in our beautiful country.

The advantages of Arbor Day then might be summed up thus: It changes the idea of young people of caring only for the present to that of providing for the future; it creates a love for the beautiful, and with this teaches certain lessons of carefulness and cleanliness; it increases the love for one's home and neighborhood because of the effort to make it beautiful and desirable to live in; it teaches love of country and service to one's country; it takes one from "nature to nature's God"; and all these things tend to produce good citizenship. Is it worth while?-Penn. School Journal.

\section{SUGGESTIONS FOR TALKS OR COMPOSITIONS}

Our Most Useful Trees.

Camping in the Big Timber.

Trees as Wind Breaks.

How to Prevent Forest Fires.

What We Owe to the Trees.

The Relation of Forests to Stream Flow.

Why We Need Our Mountains.

Uses of Shrubbery and Vines.

What a Timber Famine Would Mean.

What Trees Teach Us.

Some Famous Trees.

Why We Keep Arbor Day.

How to Make Arbor Day More Useful.

A Lumber Camp.

What Has Been Done to Protect Our State Forests?

The Trees Most Common in Our Country.

Food Which Trees Provide.

Our Native Fruit Trees and Shrubs.

The Kinds of Trees to Plant. 
The Best Way to Plant a Tree.

Proper Care of Young Trees.

Reasons for My Choice of Trees.

How the Trees Eat and Drink.

What Birds Do for Trees.

How Arbor Day Originated.

Our Most Beautiful Trees.

Why the Meadow Lark Should be Protected.

What Our Game Laws Do for Some Birds.

Imaginary Dialogue Between Two Newly Planted Trees on the School Ground.

Play Representing Imaginary Conversation Between Several Animals or Birds Which Love the Woods.

Autobiography of a Charred Pine Tree Left Standing Alone After a Forest Fire.

\section{SUGGESTIVE QUESTIONS.}

Why is Arbor Day celebrated in the spring?

Why is not the same day observed thruout the states?

What trees live longest?

What trees withstand wind storms best?

What trees are drought resisting?

What trees are most easily grown in the locality?

What trees are most rapidly grown?

What trees grow best in swampy places?

How can you tell the age of trees?

What and where is the sap wood?

Name some trees useful for their sap.

What tree produces tar, pitch and turpentine?

What wood is used for making lead pencils, and chests?

The bark of what tree is used for medicine? Spice?

What woods are most popular for furniture?

What trees do the Indians use in making canoes?

What trees give pulp for paper making?

Name six trees commonly found in Montana.

Debate: Resolved, that trees should be planted on our school grounds. 


\section{WHY PLANT TREES?}

They add value to the property.

They protect the pavement from the hot sun.

They cool the air in summer and radiate warmth in winter.

They furnish homes for thousands of birds that help man in his fight against. injurious insects.

They furnish homes for many animals that are useful to man for food and clothing.

They help man in his fight for better sanitation.

They help to keep the air pure for man and the lower animals.

They supply a large part of all the fuel in the world.

They give us wood, and wood furnishes us with building material, furniture, implements, utensils, tools and other useful things in great variety.

They furnish one of the most striking and permanent forms of beauty.

They improve the climate and conserve soil and water.

They furnish a great variety of miscellaneous, useful products.

\section{DRAPER'S “TEN COMMANDMENTS" ON TREE PLANTING}

1. Do not allow roots to be exposed to the sun, drying winds, or frost.

2. Prune, with a sharp clean cut, any broken or injured roots.

3. Have the holes large enough to admit all the roots without cramping.

4. Plant in fine loam, enriched with thoroly decomposed manure.

5. Do not allow any green unfermented manure to come in contact with roots.

6. Spread out the roots in their natural position and work fine loam among them, making it firm and compact.

7. Do not plant too deep. Let upper roots be set an inch lower than before.

8. Remove all broken branches, and cut back at least one-half of the previous year's growth of wood. 
9. If the season lacks the usual rainfall, water thoroly twice a week.

10. After-culture: Keep soil in a good degree of fertility. Mulching the trees in autumn with manure is beneficial.

\section{THE SPIRIT OF ARBOR DAY Frank A. Hill}

The spirit of Arbor Day is that of a deep love for trees -a love that includes their beauty on the one hand and their service on the other. This love has a thousand aspects and a thousand degrees, for the beauty and the service that call it forth are as varied as the trees that grow and the needs of the earth and man to which they so admirably minister. There is the beauty of the stately pine, the rugged oak, the graceful elm. There is the service of the fragrant eucalyptus that brings health to the deadly Campagna, of the versatile palm that makes habitable the waste places of the tropical belt, of the humid forest that holds back the waters of the rainy season to bless the dry that follows after. The problems of the trees are also without number. There is the problem of the East-to save its forests where now they abound. There is the problem of the West-to make forests abound where now they are unknown. A forest murderously ruined by the lumberman's axe is like a field of battle when the fighting is over-a sight to make humanity weep. Not so the forest that springs into life from the treeless plain. And so the mission of Arbor Day varies as the trees themselves. One blessed thing, however, is common to all the Arbor Days of the land we love, and that is the spirit to make the most of God's useful and beautiful trees.

\section{THE NATURE LOVER'S CREED}

I believe in Nature, and in God's out-of-doors.

I believe in pure air, fresh water and abundant sunlight.

I believe in the mountains, and as I lift up mine eyes to behold them, I receive help and strength.

I believe in the forests, where the aged may renew their youth, and the young gather stores of wisdom which shall abide with them forever. 
I believe in the highland springs and lakes, and would have noble trees stand guard around them; upon the mountain sides I would spread a thick carpet of leaves and moss thru which the water might find its way into the valleys and onward to the ocean.

I believe in protecting the birds and the animals that live amidst the trees, and the ferns and mosses and blossoming plants.

I believe in all the beautiful things of nature, and would preserve, protect and cherish them.

"Come, let's to the fields, the meads, and the mountains,

The forests invite us, the streams and the fountains."

-Mrs. P. S. Peterson.

Taken from Arbor and Bird Day Manual, Charleston, W. Va.

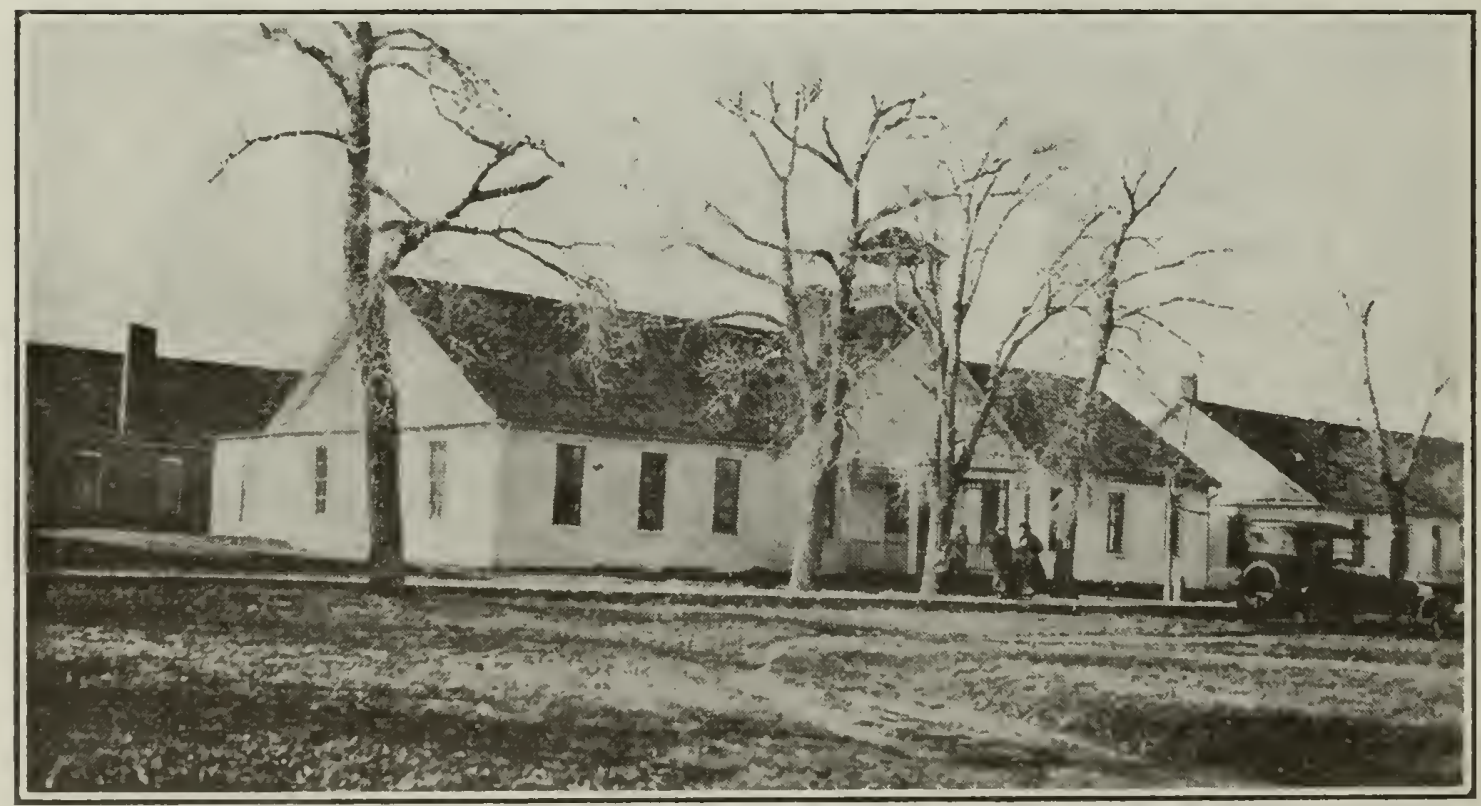

Government Two-Teacher School Building at Fort Shaw. 


\section{ARBOR DAY \\ Story of How It Came to Be.}

Give fools their gold and knaves their power;

Let fortune's bubbles rise and fall:

Who sows a field, or trains a flower,

Or plants a tree, is more than all.

-Whittier.

How Arbor Day came to be is a story well worth retelling. The originator of Arbor Day was J. Sterling Morton, one of the pioneer settlers of Nebraska, who afterward achieved prominence as a member of President Cleveland's cabinet.

On arriving in the plains country west of the Missouri, in 1855, Mr. Morton was struck by the forbidding aspect of the lonely waste then known as the "Great American Desert." Except a fringe of straggly cottonwoods and willows along the rivers, no trees were to be seen. The arid plains were supposed to be barren. Annual prairie fires destroyed the buffalo grass and other scanty herbage. It took a good deal of faith to believe that anything could be made to grow in that desolate region, yet the young man broke up the stubborn glebe and harvested a crop. He loved trees, and he sent to friends in the East for seeds and slips. These were forwarded to him, and in time trees were growing about him. He set out groves, and ere long he made an impression on his neighbors; for some of them followed his good example. Gradually others in the state came to appreciate the blessing of groves, which curbed the prairie fires and broke the force of the wintry blasts. The trees were needed, too, for fuel and lumber.

Morton's enthusiasm for trees was infectious. Time passed, and the once dreary landscape was dotted with homes. The habit of planting groves and orchards was encouraged by public men and by the press. Morton imported rare varieties for ornament as well as for use. He sought not only to teach his neighbors the value of trees-he interested members of the legislature in the subject.

Then came the inspiration for Arbor Day. The idea was favored by the State Board of Agriculture, a bill was drafted. and it was passed, setting aside one day for tree planting 


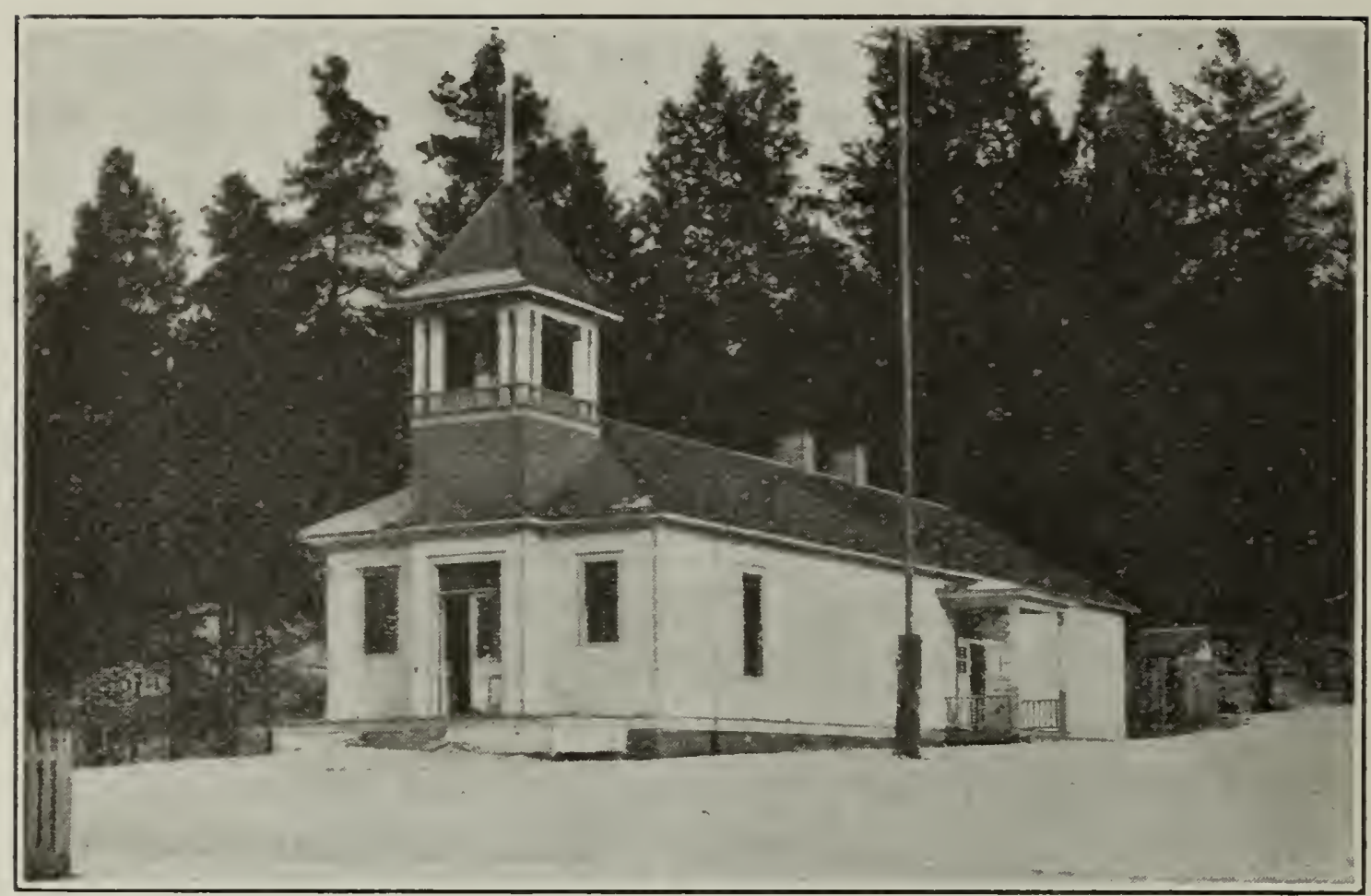

A rural school building in Flathead county showing the beauty of wooded surroundings

in Nebraska, not only by school children, but by adults. The first Arbor Day was April 10, 1872, just forty-eight years ago. A prize of one hundred dollars was offered by the State Board of Agriculture to the person who would set out the greatest number of trees on that day. Newspapers and teachers joined in the agitation; as a result, more than a million trees were planted in Nebraska that day. The practice was kept up, and other commonwealths of the Union concluded that Arbor Day was a good thing. Thus the planting of trees became widespread. During the past four decades many billions of trees have been planted in the earth. The success of the movement far exceeded anything that J. S. Morton ever dreamed of.

The old saying that he is a benefactor who causes two blades of grass to spring up where only one grew before is eminently true of the man who plants trees. Timber is one of the most valuable things in the world. Much of our wealth comes from our forests. Trees are useful for fruit, nuts, shelter, shade, fuel, ornament, and for the thousand and one purposes to which wood is put in modern life. An immense quantity of wood is required every day to supply paper for printing presses. The daily consumption of matches is simply enormous. It is said that the civilized nations of the 


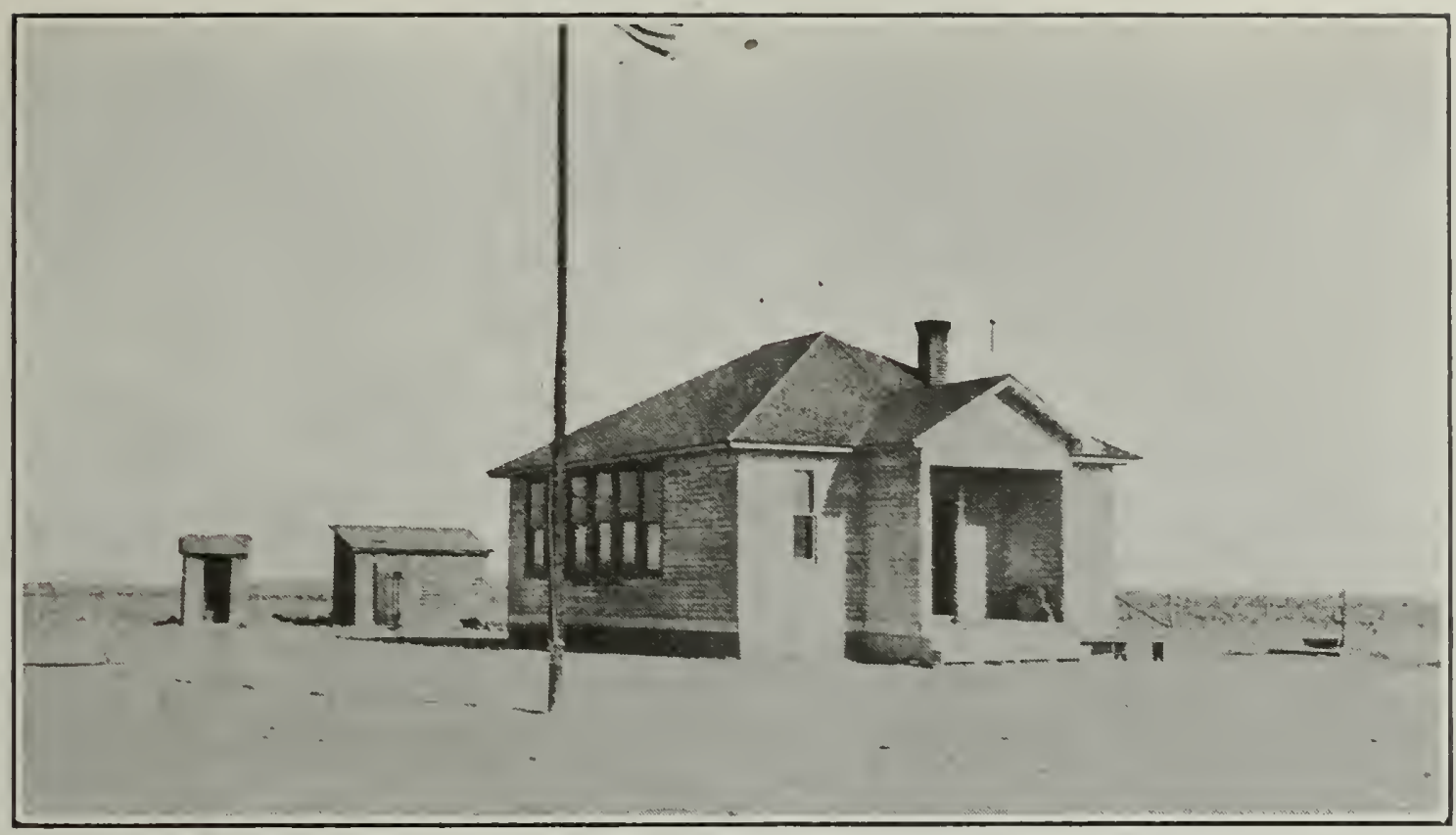

A modern rural school house in Beaverhead county which needs trees to make it more attractive

world strike three million matches every minute of the twenty-four hours. The daily consumption of matches in the United States exceeds twenty-five per capita; that is more than two billions of matches are ignited every day. The making of matches is only one of the many industries affected by the threatened shortage in the wood supply. The most suitable match timbers are pine, aspen, linden, willow, birch, poplar, and white cedar. It is desirable to plant these trees in increasing numbers every year.

There are other sides to the problem. The trees afford resting places and nesting places for our friends, the birds. They conserve moisture which feeds the streams that water the fields and gardens of our lands.

It is well that citizens and school children should realize the pressing necessity of restoring the forests. For our national greatness, we must conserve our natural resources. It is, therefore, a patriotic duty for boys and girls to engage in tree planting on Arbor Day; thus they provide for the wants of those who will come after them, and they gain a more accurate knowledge of a wonderful world.

—Colorado Arbor Day Bulletin, 1913. 


\section{ARBOR DAY. LETTER}

(Written by President Roosevelt to the School Children of the United States.)

Arbor Day (which means simply "Tree Day") is now observed in every state in our Union, and mainly in the schools. At various times, from January to December, but chiefly in the month of April, you give a day or part of a day to special exercises and perhaps to actual tree planting, in recognition of the importance of trees to us as a nation, and of what they yield in adornment, comfort, and useful products to the communities in which you live.

It is well you should celebrate your Arbor Day thotfully, for within your lifetime the nation's need of trees will become serious. We of an older generation can get along with what we have, tho with growing hardship, but in your full manhood and womanhood you will want what nature once so bountifully supplied, and man so thotlessly destroyed; and because of that want you will reproach us, not for what we have used, but for what we have wasted.

For the nation, as for the man or woman or boy or girl, the road to success is the right use of what we have and the improvement of present opportunity. If you neglect to prepare yourselves now for the duties and responsibilities which will fall upon you later, if you do not learn the things which you will need to know when your school days are over, you will suffer the consequences. So, any nation which, in its youth, lives only for the day, reaps without sowing, and consumes without husbanding, must expect the penalty of the prodigal, whose labor could with difficulty find him the bare means of life.

A people without children would face a hopeless future; a country without trees is almost as hopeless; forests which are so used that they can not renew themselves will soon vanish, and with them all their benefits. A true forest is not merely a storehouse full of wood, but, as it were, a factory of wood, and at the same time a reservoir of water. When you help to preserve our forests or plant new ones, you are acting the part of good citizens. The value of forestry deserves, therefore, to be taught in the schools, which aim to make good citizens of you. If your Arbor Day exercises help you to realize what benefits each one of you receives from the forests, and how, by your assistance, these benefits may continue, they will serve a good end. 


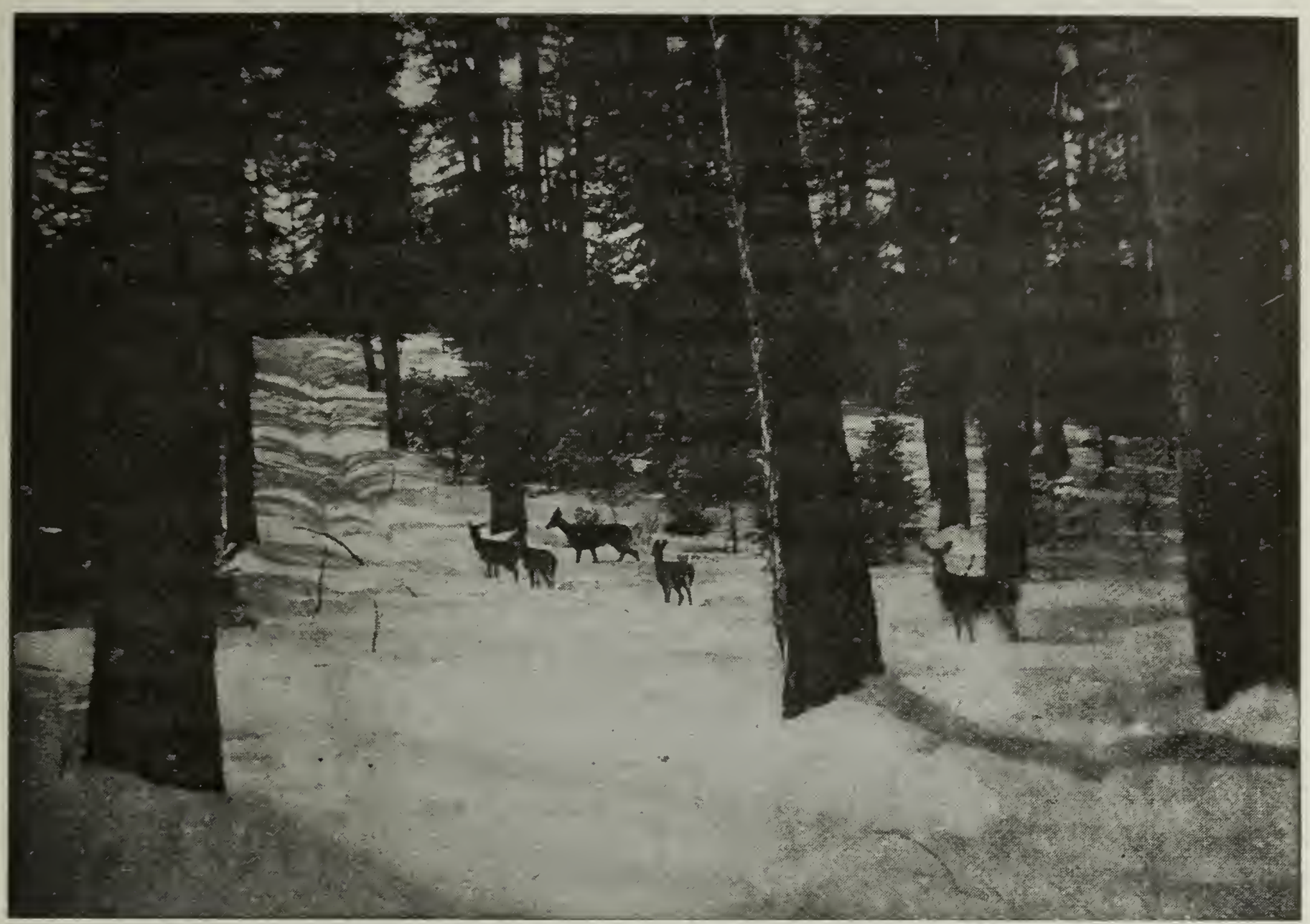

(Loaned by Department of Agriculture and Publicity) Nature Reigns Supreme

\section{THE AMERICAN FORESTS John Muir}

The forests of America, however slighted by man, must have been a great delight to God; for they were the best $\mathrm{He}$ ever planted. The whole continent was a garden, and from the beginning it seemed to be favored above all the other wild parks and gardens of the globe. To prepare the ground, it was rolled and sifted in seas with infinite loving deliberation and forethot, lifted into the light, submerged and warmed over and over again, pressed and crumpled into folds and ridges, mountains, and hills, subsoiled with heavy volcanic fires, plowed and ground and sculptured into scenery and soil with glaciers and rivers-every feature growing and changing from beauty to beauty, higher and higher. And in the fullness of time it was planted in groves, and belts, 
and broad, exuberant, mantling forest, with the largest, most varied, most fruitful and most beautiful trees in the world. Bright seas made its border with wave embroidery and icebergs; gray deserts were outspread in the middle of it, mossy tundras on the north, savannas on the south and blooming prairies and plains; while lakes and rivers shone thru all the vast forests and openings, and happy birds and beasts gave delightful animation. Everywhere, everywhere over all the blessed continent, there were beauty and melody and kindly, wholesome, foodful abundance.

These forests were composed of about five hundred species of trees, all of them in some way useful to man, ranging in size from twenty-five feet in height and less than one foot in diameter at the ground, to four hundred feet in height and more than twenty feet in diameter-lordly monarchs proclaiming the gospel of beauty like apostles. For many a century after the ice plows were melted, nature fed them and dressed them every day, working like a man, a loving, devoted, painstaking gardener; fingering every leaf and flower and mossy furrowed bole; bending, trimming, modeling, balancing; painting them with the loveliest colors: bringing over them now clouds with cooling shadows and showers, now sunshine; fanning them with gentle winds and rustling their leaves; exercising them in every fiber with storms, and pruning them; loading them with flowers and fruit, loading them with snow, and ever making them more beautiful as the years rolled by.

-Published by Houghton, Mifflin Co., Boston, Mass.

\section{OUR FRIENDS THE TREES}

\section{Emilie Yunker}

How wonderful are the trees! They give us nuts and fruits to eat. Where would the squirrels be if there were no nuts? What would the dear little birds do? I am afraid they would have no homes and no food, and they couldn't live. A dreary world this would be without our friends, the trees. I would not like to live in it. 
The water, instead of soaking into the ground, would go rushing down the hills, tearing away the good soil, causing terrible floods. Then, in summer it would be so hot and dry that we couldn't stand it. The plants would burn up.

The world is using up its trees. Let us plant more. We need them for furniture, for medicine, for firewood, for tanning leather, for building houses and ships, and for their beauty and shade.

-Published by Kentucky State Department of Education.

\section{SIZE AND AGE OF TREES}

Long before man dwelt upon the earth, the trees were here. Their boughs "piled with foliage the great hills, and reared a paradise upon a lonely plain." Not alone does geology's fascinating story disclose this fact, but the trees themselves so declare. The oldest living thing in the world is a tree. Tho they were ages old when $\mathrm{He}$ came to the earth, the very olive trees under which Jesus taught in. Palestine are still living. There is an oak tree in Dorsetshire, England, which is said to be between 1,800 and 2,000 years old. The great oak tree at Saints, France, is known to be nearly 2,000 years old. It was quite a tree, therefore, when Caesar invaded Britain. There are a number of other living trees in Europe which are known to be from 1,200 to 2,000 years old - their beginnings dating away back to Charlemagne's time and before.

An Oriental plane tree, standing near Constantinople, 150 feet in circumference, is probably as old as any living tree. Its refreshing shade was enjoyed by earth's people in the days when Pliny the Elder wrote so entertainingly about the plane trees of his interurban retreat. In the Mexican state of Oaxaco stands a vigorous cypress, 112 feet in girth, which scientists confidently declare is at least 5,000 years old, yet it shows no signs of decay or age.

Perhaps the most beautiful groves in the world are the sequoia groves of California. The trees are both wonderful and stupendous. They are the true giants of the world. These big trees thrive only in certain sheltered places which are constantly watered by snow-fed streams, at an altitude of 5,000 to 8,000 feet. 


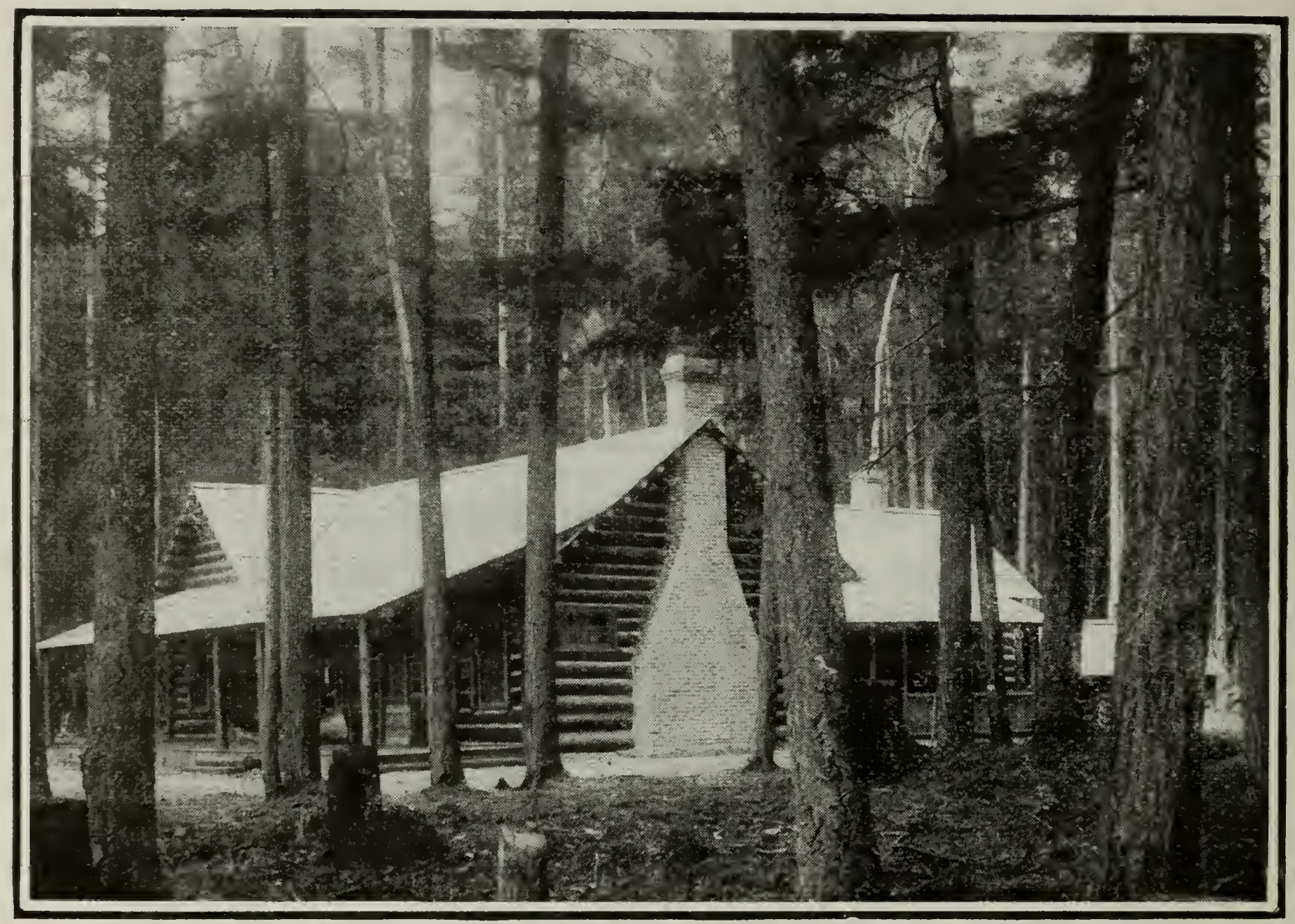

\section{Hunting Lodge in Forest}

(Loaned by Department of Agriculture and Publicity)

There is little doubt that these trees were growing before the time of Adam and Eve. A small tree of this grove was recently felled and its rings counted by three scientific men, and each reported that it was not less than 4,000 years old. Some of these trees are lying on the earth and have lain there for ages. This is amply proven by the fact that in the ditches formed by their falling, trees have appeared and grown to enormous sizes, thus proving that a sequoia may lie in the damp earth for ages without decaying. But it is not uncommon to find in some of the groves immense trees decayed, which also proves that they have lain prostrate for incalculable ages.

The tallest tree now standing in the Calaveras grove is 325 feet in height. In the valley of the Watts river in Victoria many fallen trees that lie on the ground exceed 350 feet in length. One monster giant has fallen so as to form a bridge over a stream. It was broken in falling, but the portion which remained intact measured 435 feet in length, 
and since its girth at the point of fracture is nine feet, its discoverer estimates that the perfect tree must have measured fully 500 feet in height. Its circumference, five feet above the roots, is 54 feet.

-Arbor Day in Indiana, 1918.

\section{LIST OF NOTED TREES}

The Elm tree at Philadelphia under which William Penn made his famous treaty with nineteen tribes of barbarians.

The Charter Oak at Hartford which preserved the written guarantee of the liberties of the Colony of Connecticut.

The wide-spreading Oak tree at Flushing, Long Island, under which George Fox, the founder of the Society of Friends, preached.

The lofty Cypress tree in the Dismal Swamp under which Washington reposed one night in his young manhood.

The high French Apple tree near Fort Wayne, Ind., where Little Turtle, the great Miami chief, gathered his warriors.

The Elm tree at Cambridge, in the shade of which Washington first took command of the Continental army, on a hot summer's day.

The Tulip tree on King's Mountain battlefield in South Carolina, on which ten bloodthirsty Tories were hanged at one time.

The tall Pine tree at Ft. Edward, N. Y., under which the beautiful Jane McCrea was slain.

The magnificent Black Walnut tree near Haverstraw on the Hudson at which General Wayne mustered his forces at midnight, preparatory to his gallant and successful attack on Stony Point.

The grand Magnolia tree near Charleston, S. C., under which General Lincoln held a council of war previous to surrendering the city.

The great Pecan tree at Villere's plantation, below New Orleans, under which a portion of the remains of General Packenham was buried.

The Pear trees planted, respectively, by Governor Endicott of Massachusetts and Governor Stuyvesant of New York, more than two hundred years ago. 
The Freedman's Oak, or Emancipation Oak, Hampton Institute, Hampton, Virginia, under which the slaves of this region first heard read President Lincoln's Emancipation Proclamation.

The Eliot Oak of Newton, Mass., under which the apostle, John Eliot, taught the Indians Christianity.

The old Liberty Elm of Boston planted and dedicated by a schoolmaster to the independence of the colonies, and the rallying point for patriots before, during and after the Revolutionary war.

The Burgoyne Elm at Albany, N. Y., planted the day Burgoyne was brot there a prisoner.

The Ash and Tulip trees planted at Mt. Vernon by Washington.

The Elm tree planted by General Grant on the capitol grounds at Washington.

Sequoia-Palo Alto, California.

The Cary tree planted by Alice and Phoebe Cary in 1832, a large and beautiful Sycamore seen from the Hamilton turnpike, between College Hill and Mt. Pleasant, Hamilton County, Ohio.

-American Civic Association of Philadelphia.

\section{THE FOUR APPLE TREES}

Many years ago, there was a man who wanted to have a beautiful orchard. So he sent for some young trees, knowing that he should not have to wait so long for his orchard if he planted trees which had already had a good start in growing.

Unfortunately, however, the trees arrived just at a time when the man was obliged to leave home for several days. He was afraid the trees would not live unless they were planted very soon, and he could not stay to attend to them. Just then a man came along who wanted work.

"Do you know how to set out trees?" asked the owner.

"Yes, indeed," said the other man.

"Then you may stay and set out these young apple trees. I am going to have an orchard, and I have marked the places for the trees, with stones."

By and by the owner of the trees came back and went to look at his orchard. He had been gone four days. 
"How is this?" said he, "only four trees set out?"

"That is all I had time for," said the other man. "I dug great holes, so that the roots might be spread out in the farthest tip; I hauled rich earth from the woods, so that the trees might have the best of food; I set the trees straight and filled the holes with care. This took all the time, but these four trees are well planted."

"That is too slow work for me," said the owner. "I can plant the whole orchard in one day."

So he went to work and planted the other trees in his own way. He did not dig the holes large enough or deep enough, and so many of the little rootmouths were broken off when he set the trees into the holes. He did not take pains to get soft, rich earth to fill the holes, and so the trees could not have as good food as they needed.

The poor little trees lived for a while, but they were never very strong, never bore very good apples, and at last were cut down. All that was left of the orchard were the four trees which had been planted with such faithfulness and care.

Those four trees are now older than an old man, and have been bearing delicious great apples for many, many years.

—Edward Everett Hale.

\section{STORY OF "APPLESEED JOHN"}

In the year 1806, a man living in Jefferson county, happened to look out upon the Ohio river one day when he saw floating down with the tide a strange looking craft. It consisted of two ordinary canoes lashed together. The crew was one very oddly dressed man and the cargo comprised racks of appleseeds. This singular man was John Chapman, better known as "Johnny Appleseed," from his penchant for gathering appleseeds at the cider presses in western Pennsylvania, bringing them to Ohio, planting them at suitable places, so when the pioneer came he would find an abundance of young apple trees ready for planting.

This was the mission of "Johnny Appleseed" who conscientiously believed it had been heaven sent. He was deeply religious and his faith taught him he could live as complete 


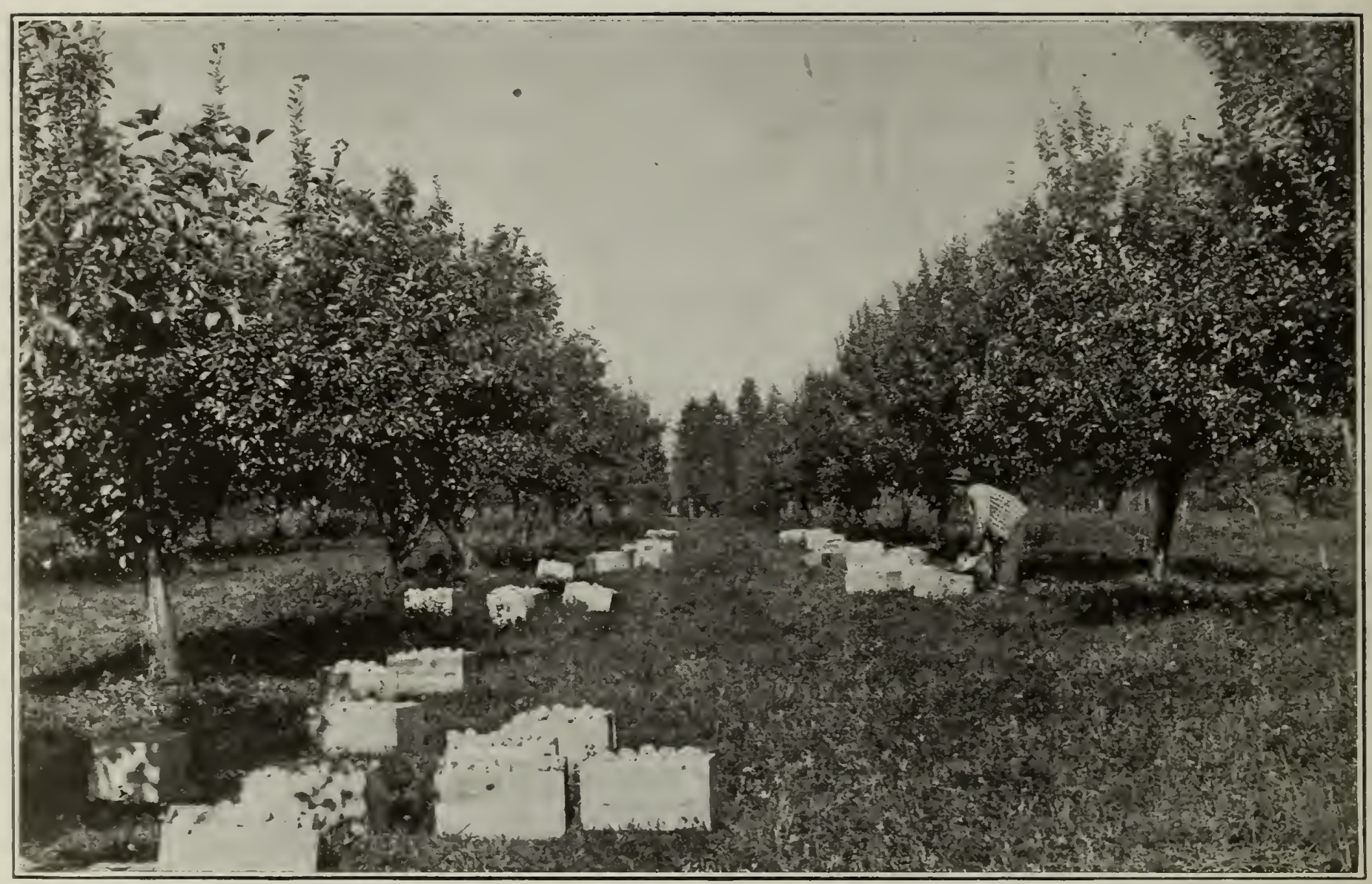

(Loaned by Department of Agriculture and Publicity) Boxing the Apple Crop

a life in thus serving his fellowmen, as in perhaps some higher (?) sphere of usefulness. Certainly the result of his labors proved a great blessing to the Ohio pioneer.

Very little is known of Johnny Appleseed before he came to Ohio. He was born in Springfield, Massachusetts, in the opening of the Revolutionary war, 1775. As a boy he loved to roam the woods, searching for plants and flowers. He was a lover of nature in all its forms. He studied the birds as well as the flowers. He loved the song of the brook as he did that of the birds. At night he would lie on his back and gaze into the sky and whether he studied flowers or stars, brooks or birds, he saw God's hand-writing in them all.

What educational advantages our tree planter enjoyed we do not know, either. But it is certain he possessed a fair knowledge of the rudiments of learning. He was a great reader for one of his time and his mode of life and, moreover, he was a clear thinker.

There are some who would call "Johnny Appleseed" "queer"; others "freakish"; again, "eccentric." The peculiar, odd personage may be described by all these terms. But 
the ruling passion of his life was to plant appleseeds, because he loved to see trees grow and because he loved his fellow men. The world has often been made better because there was a man who possessed but one idea, and he worked it for all it was worth.

"Johnny's" methods were to keep up with the van of pioneerdom and move along with it to the westward. So we find him in the early years of the century in western Pennsylvania, then Ohio, and after forty-five years of service to mankind, he dies and is buried near Ft. Wayne, Indiana.

His nurseries were usually located in the moist land along some stream. Here he would plant the seeds, surround the patch with a brush fence, and off to plant another one elsewhere. Returning at intervals to prune and care for them, he would soon have thrifty trees growing all over the country.

He did not plant these trees for money, but the pioneer got them oftentimes for old clothes, -although his usual price for each tree was "a fip-penny-bit."

The first nursery Johnny planted in Ohio was on George's Run in Jefferson county. Others he planted along the river front, when he moved into the interior of the state. For years he lived in a little rude hut in Richland county near the present town of Perrysville, from where he operated his nurseries in the counties of Richland, Ashland, Wayne, Knox and Tuscarawas.

On his journeys across the country he usually camped in the woods, altho the pioneer latch-string was always hanging out for "Appleseed Johnny." He carried his cooking utensils with him. His mush pan served him for a hat. When he would accept the hospitality of a friend, he preferred making his bed on the floor. He wore few clothes and went barefooted the most of his time, even when the weather was quite cold. For a coat a coffee sack with holes cut for neck and arms was ample.

There were plenty of Indians in those days and they were troublesome, too, since several massacres occurred in that region. But they never did any harm to our hero. No doubt they thot he was quite a "Medicine Man." Once, during the war of 1812 , when the red men were at their depredations and all the people were flocking to the Mansfield blockhouse for protection, it was necessary to get a message 
to Mt. Vernon, asking for the assistance of the militia. It was thirty miles away and the trip had to be made in the night. Johnny volunteered his services. Barefooted and bareheaded he made his way along the forest trails, where wild animals and probably wild Indians were lurking. The next morning he had returned and with him was the needed help.

He loved everything that lived. He harmed no animal and if he found any that were wounded or mistreated he would care for them as best he could. Once when a snake had bitten him, he instinctively killed it. He never quite forgave himself for this "ungodly passion."

$\mathrm{He}$, as has already been stated, was deeply religious. $\mathrm{He}$ was a disciple of Emanuel Swedenborg, and he always carried some religious books about with him, in the bosom of his shirt. These books he would give away. Often he would divide a book in several pieces, so it would go farther. When he visited the pioneers, he would always hold worship and discuss religious subjects with them.

But Johnny was getting old. The first trees he planted had for years been bearing fruit. Still he kept planting and caring for new nurseries. Once in Ft. Wayne he heard that some cattle had broken into one of them and were destroying his trees. The distance was twenty miles. He started at once to protect his property. It was in the early spring of 1845. The weather was raw and the trip was too much for him. He sought shelter at a pioneer home, partook of a bowl of bread and milk for his supper, and before retiring for the night as usual held worship.

The family never forgot that evening. How the simpleminded old man read from the Book, "Blessed are the pure in heart, for they shall see God." Then he prayed and as he spoke with God, he grew eloquent. His words made a deep impression on all who heard him.

In the morning he was found to have a high fever. Pneumonia had developed during the night. A physician was called, but the age of the man and the exposure to which he had subjected himself for so many years were against him. With the sunshine of joy and satisfaction upon his countenance as tho his dying eyes were already looking into the new Jerusalem, "God's finger touched him and he slept."

-Taken from Arbor and Bird Day Bulletin, S. D., 1914. 


\section{HOW PUSSY WILLOWS CAME}

There once lived a beautiful wood-nymph whose name was Myda. Wherever she went Myda wore a beautiful furry gray cloak. One day she was walking by the river where many willow trees grew. Suddenly a savage wolf came bounding thru the wood. Poor Myda was very frightened. Where could she hide? Quick as a flash she crouched beneath the willows and the willow branches bent down around her with their thick leaves. The fierce wolf did not see her, but went loping past her far, far away into the forest. "Dear willow trees, you have saved my life," said Myda. "I will give you my beautiful cloak, because you were so kind to me."

In the spring time when the cold, blustering March days came, the willow tree made little gray fur hoods out of Myda's cloak for all her bud-babies. Then all the children in the land called them "pussy willows," because they looked like wee, gray pussies.

- Normal Instructor and Primary Plans.

\section{THE LITTLE PINE}

Away up on the high cliff, in a ledge of rock, the little pine pushed its soft, green head thru a crack and looked around.

The mountain breeze ruffled its little topknot in a playful caress, and the mountain sun kissed it lovingly.

But "Oh, dear!" mourned the little tree. "How can I ever grow here? If I could only be across the canon on that slope with all those spruce! How grand they look! So straight and tall!

"How happy they must be, with the birds nesting in their branches-woodpeckers, bluejays, and crossbills-and chipmunks whisking and chattering among them!"

The little pine stopped. From away down below came a faint murmuring.

"Oh!" it cried, stretching itself and trying to peer over the ledge. "It's a river! I can hear it leaping and tumbling over the rocks, gurgling and splashing with joy!

"How lovely to be near it! I would have moss growing around my roots and columbines nodding and laughing in gay groups near me, and violets nestling at my feet. Oh, dear! the spruce always have the best places!" 


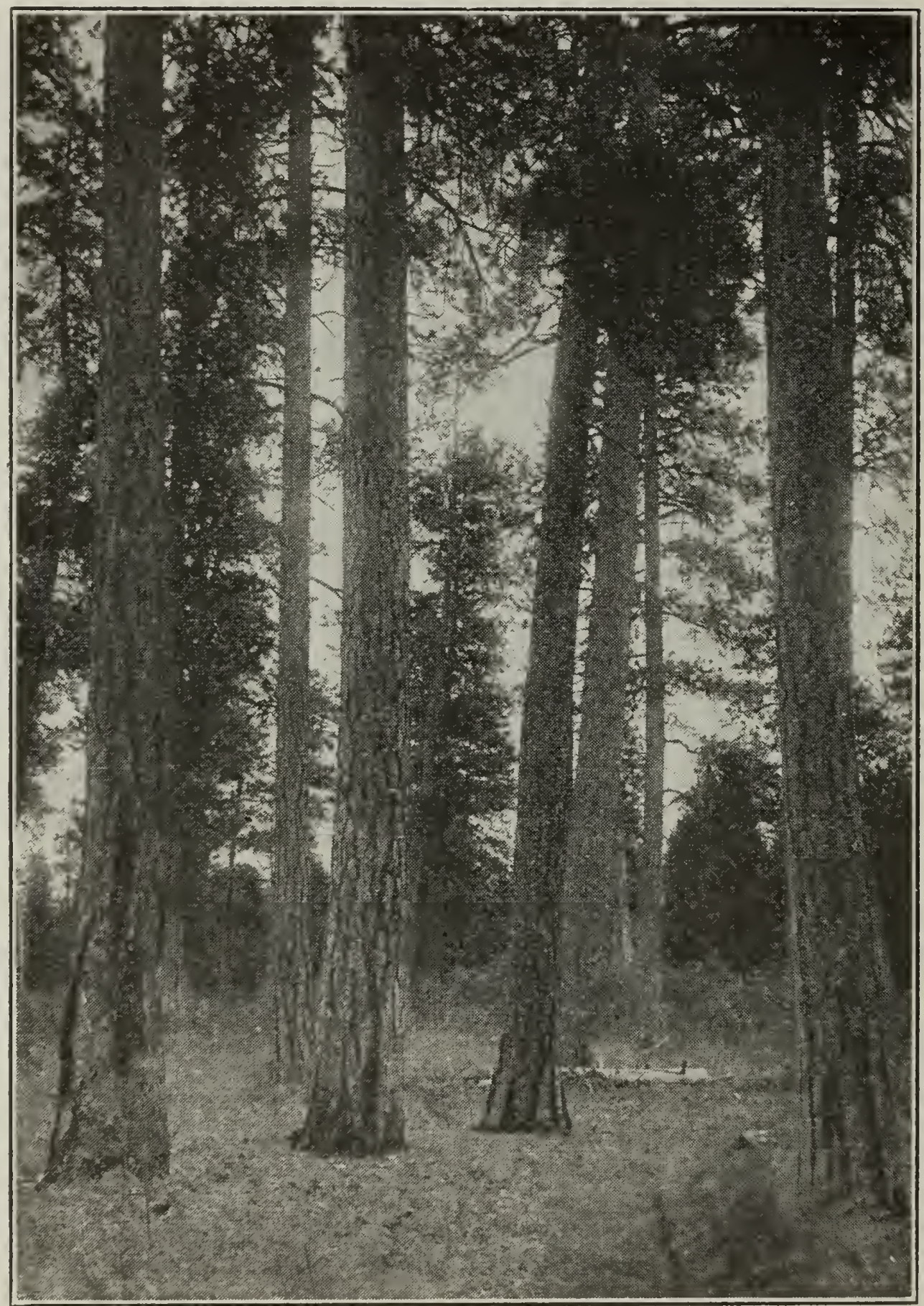

(Loaned by Department of Agriculture and Publicity) Yellow Pine near Libby

"I'll just not try to grow up here by myself at all," it sulked.

But the sky was so blue, the sun shone so warm, the winds blowing down the canon were so life-giving, and the little tree kept stretching itself so eagerly to see all the wonders above and below, that it grew in spite of itself-until one day, plunk! came its head against a rock above. For it was growing away back in a recess of the ledge.

"Now I shall have to give up and die!" groaned the despondent little thing. 
But the breeze came whispering into the recess with a message from the Mother Pine which grew on top of the cliff-near its edge, just above the little pine.

"Don't give up!" admonished the Mother Pine. "Send your roots down deep into the crack. Be sure they are good and strong. Bend over and push your head out clear of the ledge. Then you can grow straight up. You're only twenty feet below the top of the cliff. Soon you'll be tall enough to see over."

"But I shall be crooked!" wailed the little pine, "and what good is a crooked tree?"

"Every tree, even a crooked one," came back the wise voice of the Mother Pine, "has its own place in the world and its own work."

So the little pine sent its roots down deep and strong into the crack; pushed its head out over the ledge, and then straightened itself, ready to grow to the top of the cliff.

What a view it had now! It could see away up and down the canon! There was a road winding along the river, and the spruces were grander even than it had thot.

Every day the envious little pine gossiped about them to the lizard who sunned himself on the ledge beside it. The little gray reptile always hissed a softly disdainful "pooh" to it all, blinking his wise little eyes, and darting out his tongue, like a little red streak of lightning, after unwary insects.

The unhappy tree used to bewail its fate, too, to its only other friend, the great bald eagle who rested a few moments each day on his long flights up the canon. Whatever the great bird of prey might say during the conversation, at its close it always circled once or twice above the little pine; then, rising with a fierce scream of exultation, sailed majestically away. For the "king of birds" envied no spruce trees tamely rooted by a river's bank, no matter how tall and grand.

One summer, after the pine had become quite a sturdy little tree, with deep-growing roots, and its crooked trunk had grown strong-one day, as it waved its branches out over the ledge, it noticed a boy walking along the road below. The lonesome little tree, always curious about the few people who chanced along the canon road, was immediately interested, especially as the boy carried a hammer, stopping 
every now and then to chip off pieces of rock from the huge boulders along the way. Or he seemed to be picking columbines and violets across the stream, pressing them in a large portfolio he carried strapped to his back. Sometimes the pine could see him climb a tall spruce, and it knew he was peering into some nest hidden under the flat green branches; but the tree from his high lookout could see that the boy never disturbed the delicate oval treasures within the nest. So it loved the boy, and watched him eagerly as he came one bright summer day after another for his rock and flower specimens.

One day, near the end of the summer, the delightful little tree heard the boy hammering on the top of the cliff above, near the Mother Pine, and it stretched itself eagerly to see.

What happened next was frightful! There was a sound of breaking. stone and sliding gravel. A high rock crashed thru the branches of the straining tree. There was a cry, and a boy's body hurtled thru the air.

The little pine braced itself, and leaned out as far as it could reach over the ledge, and caught the boy's jacket on a short, jagged branch, while the boy himself clung for his life to the crooked trunk.

For a few terrible seconds he hung there! Then, wrenching his jacket loose, he climbed slowly down to the ledge, leaning back sick and dizzy.

By and by the color came back to his face. Two boyish arms flung around the twisted, gnarled trunk, while a boy's voice whispered tremulously: "Oh, you little pine! I shall never forget you!"

And the happy little tree waved its branches proudly over the ledge, as a boyish figure climbed back over the cliff.

The next day, after his usual visit to his crooked friend on the ledge, the gray lizard slid away, wondering why the little pine no longer seemed to envy the grand spruce across the canon.

The great bald eagle, too, poising on the ledge for a few moments' rest, as he rose circling and screaming to continue his lofty flight, was pondering why his dejected little friend had become so gay and grieved no more over his twisted trunk. 
You see, no one but the Mother Pine, standing above ready to shake down seed-bearing cones for baby trees, knew the great joy that had come to her child-knew that the little pine had found its mission and was happy in its place on the ledge away up on the cliff.

And only the Mother Pine knew that, with every breeze which rustled the branches of the little tree and fluttered a fragment of gray jacket caught on a jagged branch, the little pine heard a boyish voice calling down from the top of the cliff: "Good bye, little tree! I shall never forget you!"

-Annie Ragland Randell.

When we plant a tree, we are doing what we can to make our planet a more wholesome and happier dwelling place for those who come after us, if not for ourselves.-Holmes.

The great demand is that the school of the time shall blend nature in books with nature as it is in life.-A. E. Winship.

A people without children would face a hopeless future; a country without trees is almost as hopeless.-Roosevelt.

In so far as I know, only two things retain their youth, a tree and truth.- Holmes.

How good to lie a little while

And look up thru the tree!

The sky is like a kind big smile

Bent sweetly over me.

-Abbie Farwell Brown.

He that planteth a tree is a servant of God;

He provides a kindness for many generations,

And faces that he has not seen shall bless him.

- Van Dyke.

Summer or winter, day or night,

The woods are ever a new delight. 


\section{WHY THE EVERGREEN TREES NEVER LOSE THEIR LEAVES}

Winter was coming, and the birds had flown far to the south, where the air was warm and they could find berries to eat. One little bird had broken its wing and could not fly with the others. It was alone in the cold world of frost and snow. The forest looked warm and it made its way to the trees as well as it could to ask for help.

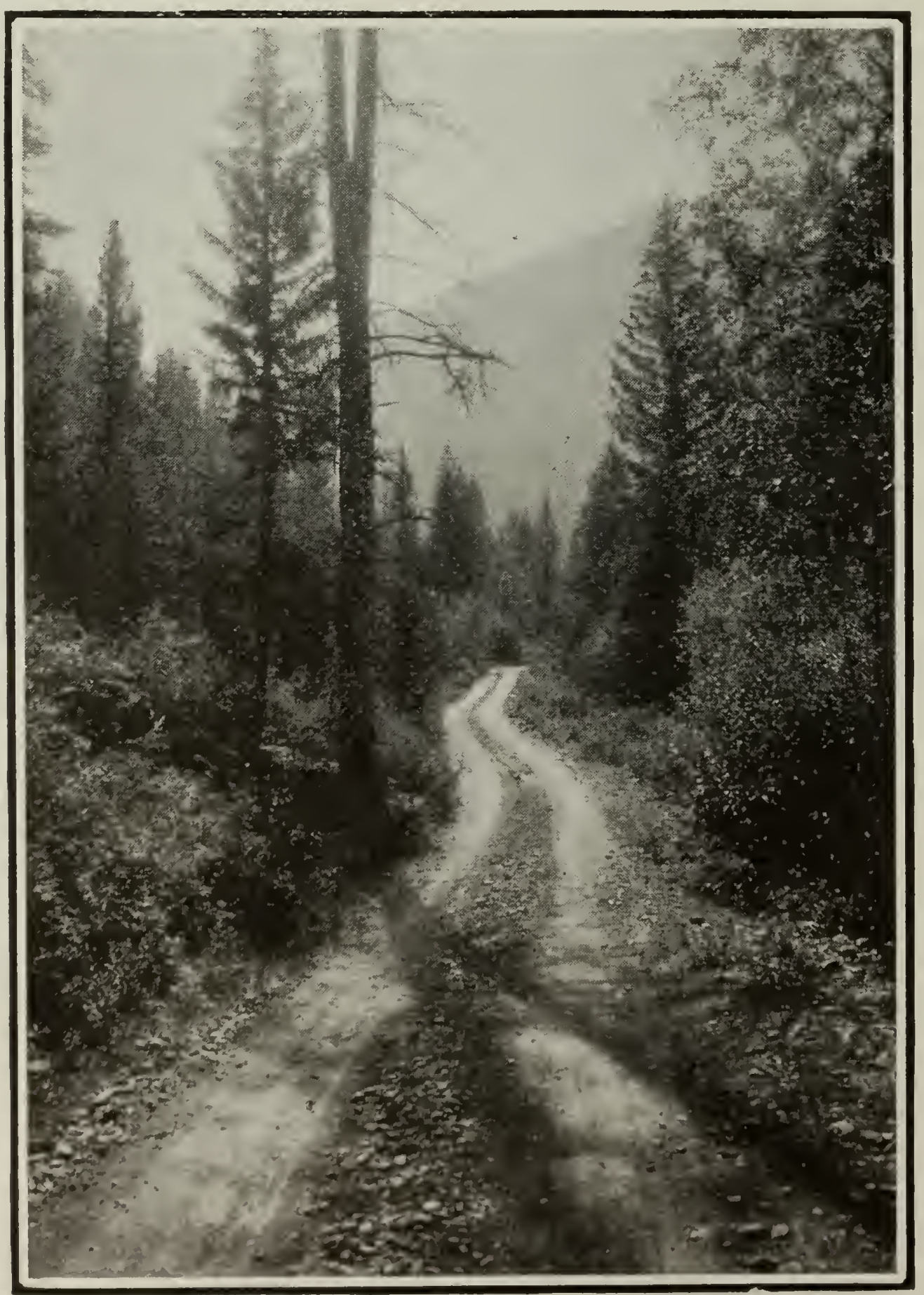

(Toaned by Department of Agriculture and Publicity) Thru the Woods 
First it came to a birch tree. "Beautiful birch tree," it said, "my wing is broken, and my friends have flown away. May I live among your branches till they come back to me?"

"No, indeed," answered the birch tree, drawing her fair green leaves away. "We of the great forest have our own birds to help. I can do nothing for you."

"The birch is not very strong," said the little bird to itself, "and it might be that she could not hold me easily. I will ask the oak." So the bird said, "Great oak tree, you are so strong, will you not let me live on your boughs till my friends come back in the springtime?"

"In the springtime!" cried the oak. "That is a long way off. How do I know what you might do in all that time? Birds are always looking for something to eat, and you might even eat up some of my acorns."

"It may be that the willow will be kind to me," thot the bird, and it said, "Gentle willow, my wing is broken and I could not fly to the south with the other birds. May I live on your branches till the springtime?"

The willow did not look gentle then, for she drew herself up proudly and said, "Indeed, I do not know you, and we willows never talk to people whom we do not know. Very likely there are trees somewhere that will take in strange birds. Leave me at once."

The poor little bird did not know what to do. Its wing was not yet strong, but it began to fly away as well as it could. Before it had gone far, a voice was heard. "Little bird," it said, "where are you going?"

"Indeed, I do not know," answered the bird sadly. "I am very cold."

"Come right here, then," said the friendly spruce tree, for it was her voice that had called. "You shall live on my warmest branch all winter if you choose."

"Will you really let me?" asked the little bird eagerly.

"Indeed, I will," answered the kind hearted spruce tree. "If your friends have flown away, it is time for the trees to help you. Here is the branch where my leaves are thickest and softest."

"My branches are not very thick," said the friendly pine tree, "but I am big and strong, and I can keep the north wind from you and the spruce." 
"I can help, too," said the little juniper tree. "I can give you berries all winter long, and every bird knows that juniper berries are good."

So the spruce gave the lonely little bird a home, the pine kept the cold north wind away from it, and the juniper gave it berries to eat.

The other trees looked on and talked together wisely.

"I would not have strange birds on my boughs," said the birch.

"I shall not give my acorns away for any one," said the oak.

"I never have anything to do with strangers," said the willow, and the three trees drew their leaves closely about them.

In the morning all those shining green leaves lay on the ground, for a cold north wind had come in the night, and every leaf that it touched fell from the tree.

"May I touch every leaf in the forest?" asked the wind in its frolic.

"No," said the frost king. "The trees that have been kind to the little bird with the broken wing may keep their leaves!"

This is why the leaves of the spruce, the pine and the juniper are always green.-From the Book of Nature Myths.

\section{THE PRIMEVAL FOREST}

This is the forest primeval. The murmuring pines and the hemlocks,

Bearded with moss, and in garments green indistinct in the twilight,

Stand like Druids of eld, with voices sad and prophetic.

Stand like harpers hoar, with beards that rest on their bosoms.

Loud from its rocky caverns, the deep-voiced neighboring ocean

Speaks, and in accents disconsolate answers the wail of the forest,

This is the forest primeval; but where are the hearts that beneath it

Leaped like the roe, when he hears in the woodland the voice of the huntsman? 


\section{WHO LOVES THE TREES BEST?}

Who loves the trees best?

"I," said the spring.

"Their leaves so beautiful

To them I bring."

Who loves the trees best?

"I," summer said,

"I give them blossoms, White, yellow, red."

Who loves the trees best?

"I," said the fall,

"I give luscious fruits, Bright tints to all!"

Who loves the trees best?

"I love them best,"

Harsh winter answered, "Give them rest!"

- The Independent.

\section{PLANTING A TREE}

What do we plant, when we plant the tree?

We plant the ship which will cross the sea;

We plant the mast to carry the sails;

We plant the planks to withstand the gales-

The keel, the keelson, and beam and knee;

We plant the ship when we plant the tree.

What do we plant, when we plant the tree?

We plant the houses for you and me;

We plant the rafters, the shingles, the floors;

We plant the studding, the lath, the doors;

The beams and siding, all parts that be;

We plant the house when we plant the tree.

What do we plant, when we plant the tree?

A thousand things that we daily see;

We plant the spire that out-towers the crag;

We plant the staff for our country's flag;

We plant the shade, from the hot sun free;

We plant all these when we plant the tree. 


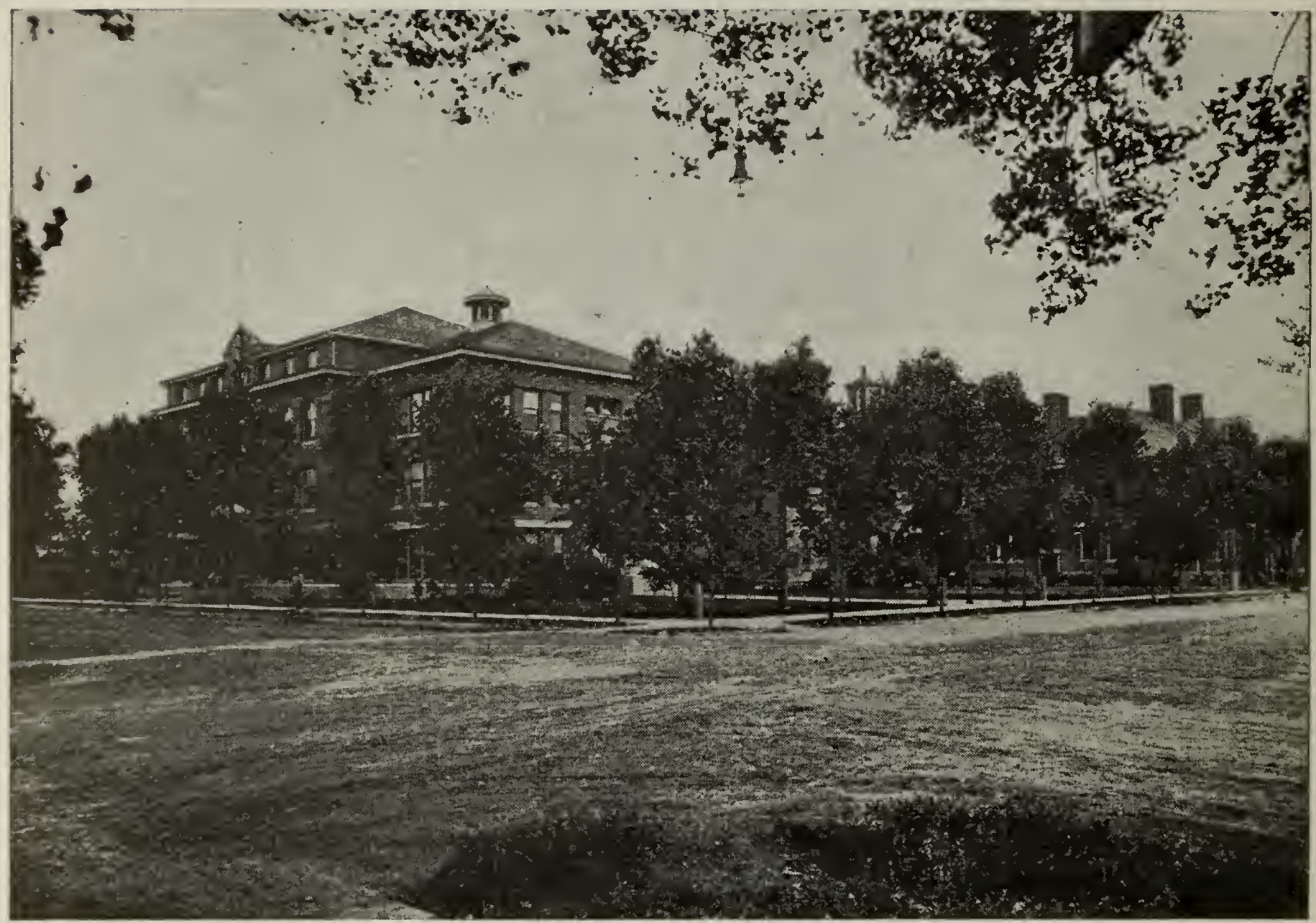

(Loaned by Department of Agriculture and Publicity) A school building in Billings around which shade trees were planted years ago

\section{TREES}

However little I may be

At least I, too, can plant a tree,

And some day it will grow up so high

That it can whisper to the sky.

And spread its leafy branches wide

To make a shade on every side.

Then on a sultry summer day,

The people resting there will say-

"Oh, good, and wise, and great was he

Who thot to plant this blessed tree!"

To avert treelessness; to impreve the climatic conditions; for the sanitation and emrellishment of home environments; for the love of the beautiful and useful combined in the music and majesty of a tree as fancy and truth unite in an epic poem, Arbor Day was created. It has grown with the vigor and beneficence of a grand truth, or a great tree.-J. Sterling Morton. 


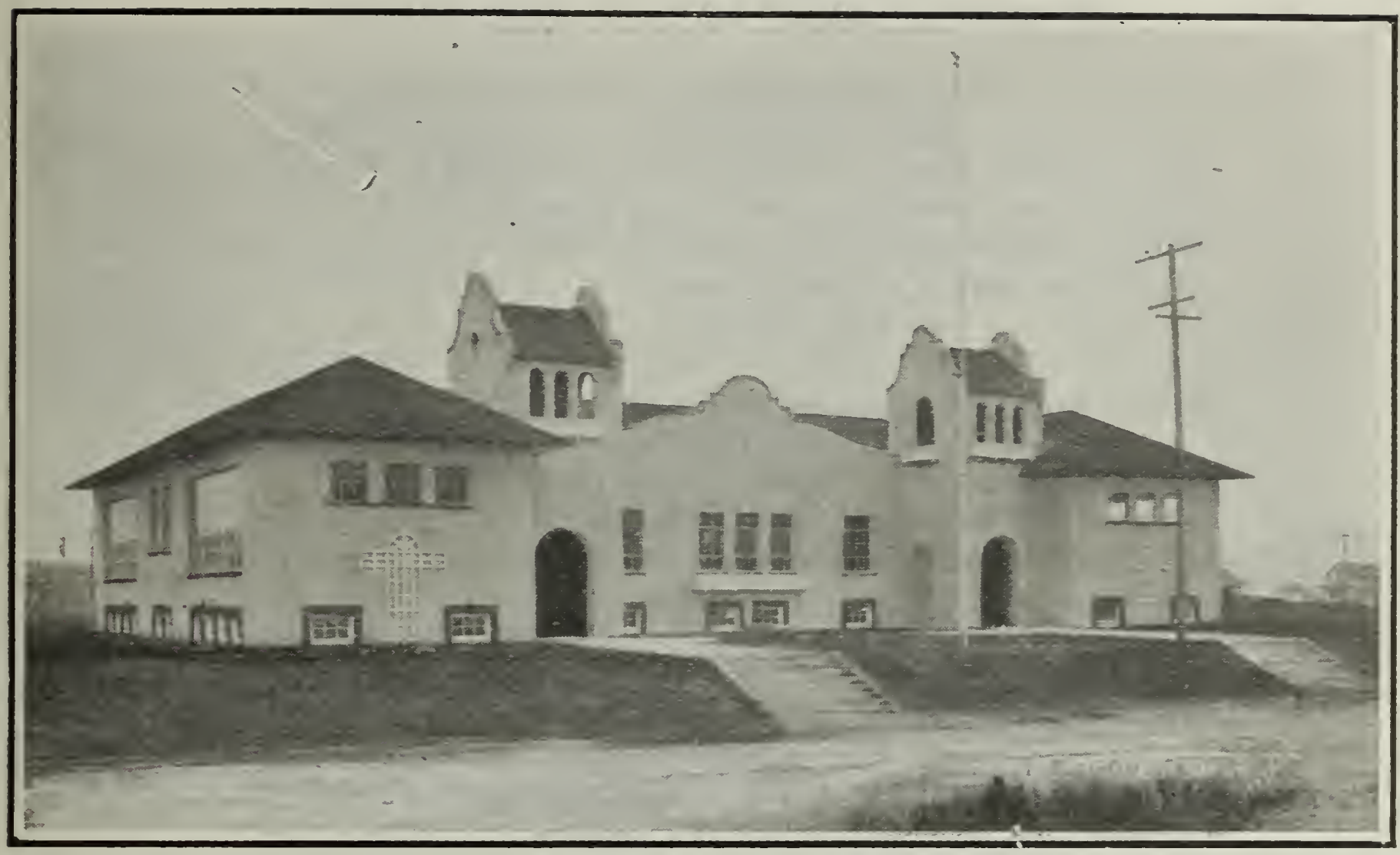

(Loaned by Department of Agriculture and Publicity)

This fine new building at Lewistown will be much more attractive as soon as trees arow un on the grounds

\section{ANTICIPATION}

I am going to plant a hickory tree, And then when I am a man, My boys and girls may come and eat Just all the nuts they can!

And I shall say, "My children dear, This tree that you enjoy

I set for you one Arbor Day, When I was but a boy."

And they will answer, "Oh, how kind To plant for us this tree!" And then they'll crack the fattest nuts, And give them all to me!

-Youth's Companion.

The tree planter and teacher united in one shall be declared the best benefactor of modern times-the chief provider of posterity.-J. Sterling Morton. 


\section{AN APPLE ORCHARD IN THE SPRING.}

Have you seen an apple orchard in the spring?

\section{In the spring?}

An English apple orchard in the spring?

When the spreading trees are hoary.

With their wealth of promised glory,

And the mavis sings its story

In the spring?

Have you plucked the apple blossoms in the spring?

In the spring?

And caught their subtle odors in the spring?

Pink buds bursting at the light,

Crumpled petals baby-white,

Just to touch them a delight-

In the spring?

Have you walked beneath the blossoms in the spring?

In the spring?

Beneath the apple blossoms in the spring?

When the pink cascades are falling,

And the silver brooklets brawling,

And the cuckoo bird soft calling,

In the spring?

If you have not, then you know not, in the spring,

In the spring?

Half the color, beauty, wonder of the spring.

No such sight can I remember

Half so precious, half so tender,

As the apple blossoms render

In the spring?

-William Martin.

\section{PINE NEEDLES}

If Mother Nature patches

The leaves of trees and vines,

I'm sure she does her darning

With the needles of the pines.

They are so long and slender;

And sometimes in full view,

They have their thread of cobwebs,

And thimbles made of dew.

-William H. Hayne.

"He who plants trees loves others besides himself." 


\section{THE TREE'S DREAM}

Little green tree, so slim and small, Standing under the school house wall, Planted there upon Arbor Day,

Tell me, what are you doing, say?

So quiet you stand, and so still you keep, I really believe you have gone to sleep.

"Oh! I'm dreaming now," said the little tree, "Of pleasant days that are to be, Of the robins and bluebirds that every spring Will come and sit in my boughs and sing. Oh! Plenty of company I shall see In my gay green tent," said the little tree.

"Im dreaming of all the little girls, In gingham aprons and yellow curls, That under the shade of my leafy boughs Will make for themselves a wee playhouse, With nice bur-baskets, the dear little souls, And pepper-pod teapots, and sugar bowls.

"I'm dreaming of all the barefoot boys That will fill my branches with meiry noise, And climb my limbs like an easy stair, And shake down my nuts till the boughs are bare. Oh! A jolly good comrade I shall be When I grow up!" said the little tree.

-Elizabeth H. Thomas.

\section{THE TREE'S FRIEND}

"Oh, the tree loves me," said the tiny flower, "For he shades me all the day, From the sun's fierce heat or the pelting rain And content at his feet I stay."

"Oh, the tree loves me," sang the happy bird, "My nest on his mighty arm

Is fastened safe, and my babies rock In their cradles safe from harm."

"Oh, the tree loves me," said the little child, "For he gives me blossoms sweet, Then the sun shines warm on his laden boughs, Till the ripe fruit drops at my feet." 


\section{THE APPLE TREE}

When an apple tree is ready for the world to come and eat, There isn't any structure in the land that's "got it beat." There's nothing man has builded with the beauty or the charm That can touch the simple grandeur of the monarch of the farm There's never any picture from a human being's brush

That has ever caught the redness of a single apple's blush.

When an apple tree's in blossom it is glorious to see,

But that's just a hint at springtime, of the better things to be;

That is just a fairy promise from the Great Magician's wand of the wonders and the splendors that are waiting just beyond The distant edge of summer; just a forecast of the treat

When the apple tree is ready for the world to come and eat.

Architects of splendid vision long have labored on the earth,

And have raised their dreams in marble and we've marveled at their worth;

Long the spires of costly churches have looked upward at the sky;

Rich in promise and in beauty they have cheered the passerby.

But I'm sure there's nothing finer for the eye of man to meet

Than an apple tree that's ready for the world to come and eat.

There's the promise of the apples, red and gleaming in the sun,

Like the medals worn by mortals as rewards for labors done;

And the big arms stretched wide open, with a welcome warm and true In a way that sets you thinking it's intended just for you.

There is nothing with a beauty so entrancing, so complete,

As an apple tree that's ready for the world to come and eat.

-Edgar A. Guest.

(Published by Reilly \& Britton Co.)

\section{AN ARBOR DAY TREE}

Dear little tree that we plant today,

What will you be when we're old and gray?

"The savings bank of the squirrel and mouse,

For robin and wren an apartment house,

The dressing room of the butterfly's ball,

The locust's and katydid's concert hall,

The schoolboy's ladder in pleasant June,

The schoolgirl's tent in the July noon,

And my leaves shall whisper them merrily

A tale of the children who planted me."

-Unknown.

The best and highest thing a man can do in a day is to sow a seed, whether it be in the shape of a word, an act, or an acorn.-James Boyle O'Reilly. 


\section{LITTLE EVERGREENS, GROW！}

Hey! little evergreens,

Sturdy and strong!

Summer and autumn time,

Hasten along.

Harvest the sunbeams, then

Bind them in sheaves,

Range them and change them

To tufts of green leaves.

Delve in the mellow mold,

Far, far below,

And so,

Little evergreens, grow!

Up, up so airily

To the blue sky,

Lift up your leafy tips

Stately and high;

Clasp tight your tiny cones,

Tawny and brown;

By and by, buffeting,

Rains will pelt down,

By and by, bitterly,

Chill winds will blow.

And so,

Little evergreens, grow!

Grow, grow!

Grow, little evergreens, grow!

Gather all uttermost

Beauty, because-

Hark, till I tell it now-

How Santa Claus,

Out of the northern land,

Over the seas,

Soon shall come seeking you,

Evergreen trees!

Seek you with reindeer, soon, Over the snow.

And so,

Little evergreens, grow!

Grow, grow!

Grow, little evergreens, grow! 
What if the maple flare Flaunting and red, You will bear waxen-white Tapers instead.

What if now, otherwhere, Birds are beguiled, You shall yet nestle The little Christ-child! Ah, the strange splendor The fir tree shall know. And so,

Little evergreens, grow! Grow, grow!

Grow, little evergreens, grow!

\section{PUSSY WILLOW}

Pussy willow wakened From her winter nap, For the lively Spring Breeze On her door would tap.

"It is chilly weather Tho the sun feels good; I will wrap up warmly; Wear my furry hood."

Mistress Pussy Willow Opened wide her door; Never had the sunshine Seemed so bright before.
Never had the brooklet Seemed so full of cheer; "Good morning, Pussy Willow, Welcome to you, dear!"

Never guest was quainterPussy came to town In a hood of silver gray And a coat of brown.

Happy little children Cried with laugh and shout, "Spring is coming, coming, Pussy Willow's out!"

-Kate L. Brown.

One impulse from a vernal wood May teach you more of man, Of moral evil and of good, Than all the sages can.

-Wadsworth.

'Tis education forms the common mind; Just as the twig is bent the tree's inclined. -Alexander Pope.

A man who plants a tree and cares for it, has added at least his mite to God's creation.-Lucy Larcom. 


\section{A WORLD-WIDE ARBOR DAY}

Any number of boys and girls to represent the foreign countries mentioned in play; four boys or girls to represent the different sections of our own country; and one girl for the Arbor Queen.

\section{COSTUMES.}

The Arbor Queen should wear a thin white dress adorned with flowers and leaves. The others wear characteristic costumes to correspond with the part represented.

\section{SCENE.}

\section{"Under the Greenwood Tree"}

The American children are discovered with baskets or bouquets of flowers.

\section{All-}

Once more we meet to celebrate

This gladsome Arbor Day;

From North and South and East and West

We bring our flowers gay.

\section{Northern Child-}

I come from the rugged Northern land

With its perfume of the pine;

At our cottage doors the lilacs bloom

And the morning glories twine.

\section{Southern Child-}

I come from the sunny Southern land

Where the warm Gulf breezes blow,

Where the cypress vine and the jessamine

And the orange blossoms grow.

\section{Western Child-}

I bring the wild rose from the West

That blooms so fair and free,

And the daisies from the mauntain side

That are so dear to me.

\section{Eastern Child-}

From the East I bring these favorites-

The modest violet blue,

The arbutus of Pilgrim fame,

And the dainty primrose, too. 
All-

Together we'll twine these garlands gay,

With sprigs of evergreen,

And we'll make a crown of daintiest hues,

For our lovely Arbor Queen.

(Music, while all twine flowers with evergreens or leaves to form a crown or chaplet. As the music continues, the Arbor Queen trips upon the stage. The chaplet is placed upon her head and others dance about her. Suddenly all stop and gaze toward $R$. The music ceases for a moment while all recite, then resumes again as guests enter.)

\section{All-(looking toward R.) -}

Oh, here are the guests from other lands,

With garlands sweet and fair;

Our heartiest greetings we'll extend,

Our pleasures with them share.

(Enter guests. American children may wave handkerchiefs as they enter and sing or recite the following):

Oh, welcome, welcome, welcome,

Our friends from far away!

Oh, welcome, welcome, welcome,

On this bright Arbor Day!

(All take position in form of semi-circle as follows: Queen at center; Southern and Eastern children at R., and Northern and Western children at L. of Queen. Others stand at right and left to suit convenience.)

\section{Guests-}

Good morning, little Americans, And pray how do you do?

O'er land and sea we've come today

With floral gifts for you.

From many lands and many climes,

From leagues and leagues away,

We've come to help you celebrate

This world-wide Arbor Day.

We've brought with us these native flowers-

The ones we love the best;

The sweetest blooms from Eastern lands,

The fairest from the West. 
Japan-

From far-away Japan I bring The cherry blossoms sweet,

At home they're blooming everywhere-

On lawn and public street.

\section{Hindoo-}

The dainty poppies I have brought,

From the plains of Hindustan;

You should see them dance and sway in the breeze Like a merry, fairy band.

\section{Egyptian-}

From Egypt's storied Nile I bring These lovely lotus blooms;

They speak to you of the pyramids, And the Pharaohs' ancient tombs.

\section{Briton-}

And I have brought from England's shores,

These roses red for you;

They stand for courage and for strength,

For loyal hearts and true.

\section{Scot-}

From Scotland's rugged hills I bring

This homely thistle-blow,

For once it saved an army great-

That's why we love it so.

\section{Irish-}

I've brought from dear old Ireland

These little shamrocks green,

And every Irish heart is glad

When this little plant is seen.

\section{Dutch-}

I bring you these tulips dainty and rare, From the distant Netherlands:

The gifts of peace and love are they

From friendly hearts and hands.

\section{Swiss-}

From far up on the Alpine slopes

In Switzerland, I bring

The hardy little Edelweiss,

Of which the poets sing. 


\section{France-}

I bring the lovely fleur-de-lis From sunny fields of France;

It blooms so fair in park and field

Where children love to dance.

Mexican-

I bring the wonderful cactus bloom

From the land of Mexico;

It thrives on the sandy desert plains

Where no other plant will grow.

All-

Yes, we have brought our native flowersThe ones we love the best-

The sweetest blooms from Eastern lands,

The fairest from the West.

(All sing to tune of "We Love to Make Sweet Music.")

We'll sing a song of garlands-

The shamrock and the rose.

The lotus and the cherry, And every flower that grows;

From Egypt and from England,

From France and far Cathay,

We've come to make us merry,

This joyful Arbor Day.

Oh, sing a song of posies-

The poppy and the peach,

The orange and the lily,

Oh, sing a song of each.

From frigid land and tropics,

From hill and dale away, We've come to make us merry,

This world-wide Arbor Day.

(All may dance about the Arbor Queen if desired.)

Curtain.

The tune, "We Love to Make Sweet Music," is found in the "Merry Melodies," price 15 cents. Address the author or publishers of School Education. Book rights reserved by the author.

-Willis N. Bugbee, from School Education. 


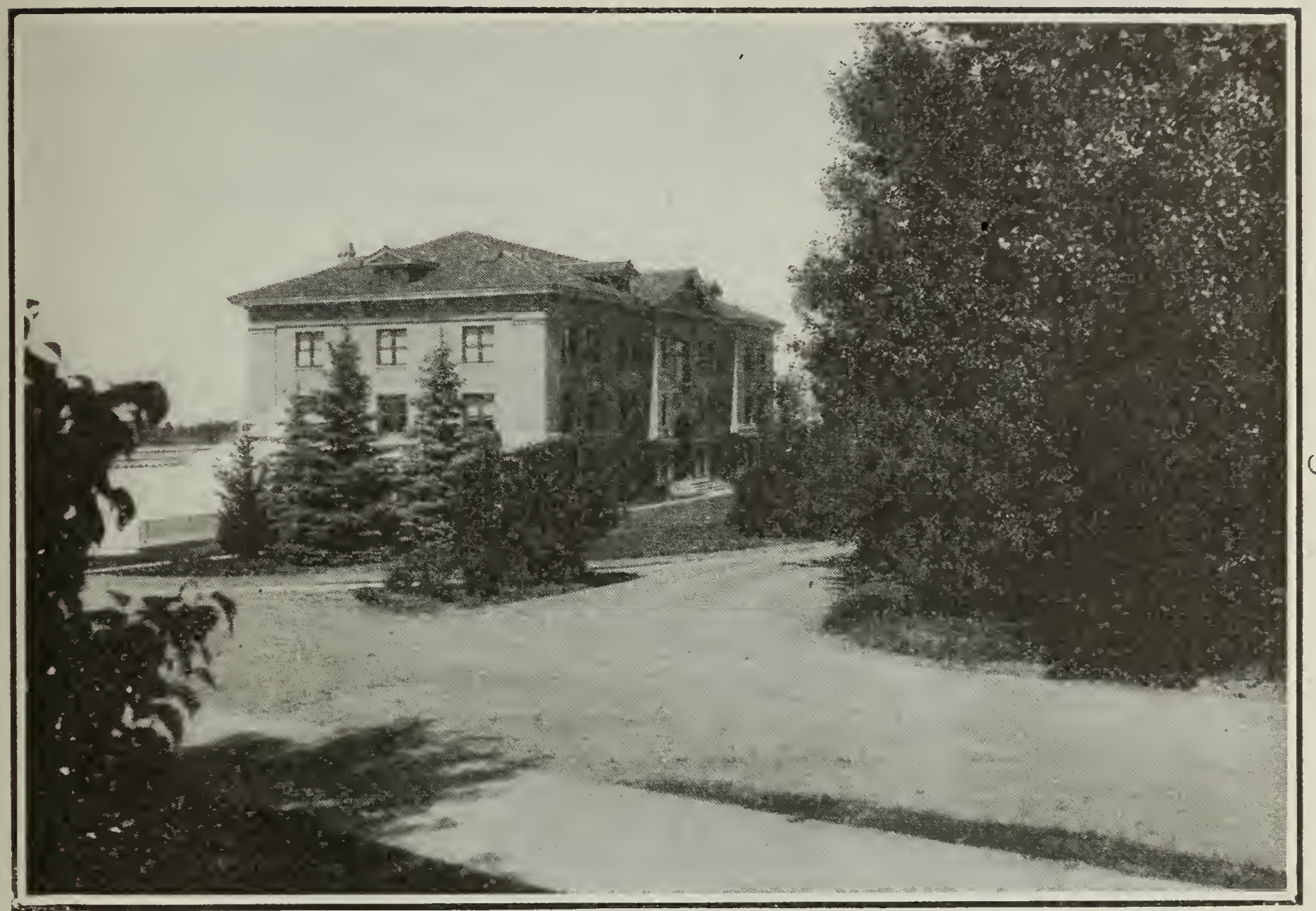

(Loaned by Department of Agriculture and Publicity) Agricultural Hall, Bozeman

\section{WHY WE PLANT THE TREE}

\section{First Pupil-}

We plant the tree for the shade it gives; For the shade of a leafy tree

On a summer's day when the hot sun shines Is a pleasure for all to see.

\section{Second Pupil-}

We plant the tree for the wood to use In winter to keep us warm,

And for hall and church and store and house, To have shelter from the storm.

\section{Third Pupil-}

We plant the tree to please the eye, For who does not like to see, Whether on hill or plain or dale, The beauty of a tree? 


\section{Fourth Pupil-}

We plant the tree for the dear birds' sake,

For they can take their rest,

While the mate sings songs of love and cheer

To the mother on her nest.

-Primary Education.

\section{BLESSING FOR THE TREE PLANTER}

$O$ painter of the fruits and flowers!

We thank Thee for Thy wise design,

Whereby these human hands of ours

In nature's garden work with Thine.

Give fools their gold and knaves their power;

Let fortune's bubbles rise and fall;

Who sows a field or trains a flower

Or plants a tree is more than all.

For he who blesses most is blest;

And God and man shall own his worth

Who toils to leave as his bequest

An added beauty to the earth.

And, soon or late, to all who sow,

The time of harvest shall be given;

The flower shall bloom, the fruit shall grow,

If not on earth, at last in heaven.

\section{THREE LITTLE TREES}

(Recitation for a tiny girl. Three other children stand near representing the trees-laughing, whispering, telling secrets, clapping hands, etc., in pretty pantomime to the speaker's words.)

Away out in the orchard in sunshine and breeze,

A-laughing and whispering, grew three little trees.

And one was a plum tree, and one was a pear,

And one was a rosy-cheeked apple tree rare.

A dear little secret, as sweet as could be,

The breeze told one day to the glad apple tree.

She rustled her little green leaves all about,

And smiled at the plum, and the secret was out.

The plum told in whispers the pear by the gate,

And she told it to me, so you see, it came straight.

The breeze told the apple, the apple the plum,

The plum told the pear, "Robin Readbreast has come!"

And out in the orchard they danced in the breeze,

And clapped their hands softly, these three little trees. 


\section{PUSSY WILLOWS}

I have some dainty pussies here All dressed in soft gray fur, But you might listen all day long And not once hear them purr.

Nor do they run and frisk about These pretty living thingsBut closely round a slender twig Each tiny pussy clings.

All thru the winter's storms and cold, These furry babies swung In cradle beds of shining brown, On willow branches hung.

The rough winds sang their lullaby And rocked them to and fro, And all about their sleepy heads Drifted the cold white snow.

But by and by the sunbeams warm Peeped into each small bed, And said, "Come, pussies, waken now, For winter days are fled."

So bravely come the pussies forth, Tho shrill the cold wind blows, And up and down the long, brown stems They cling in shining rows.

But when the days grow long and bright, And breezes not so cold, They'll change their dress of silver fur For robes of green and gold.

-Mary E. Plummer. From "Songs of the Treetop and Meadow," Published by Public School Publishing Co.

\section{THE HEART OF THE TREE}

What does he plant who plants a tree?

He plants the friend of sun and sky;

He plants the flag of breezes free;

The shaft of beauty towering high;

He plants a home to heaven anigh,

For song and mother-croon of bird

In hushed and happy twilight heard-

The treble of heaven's harmony-

These things he plants who plants a tree. 
What does he plant who plants a tree? He plants cool shade and tender rain, And seed and bud of days to be, And years that fade and flush again; He plants the glory of the plain;

He plants the forest's heritage;

The harvest of a coming age;

The joy that unborn eyes shall see-

These things he plants who plants a tree.

What does he plant who plants a tree?

He plants, in sap and leaf and wood,

In love of home and loyalty

And far-cast thought of civic good-

His blessings on the neighborhood,

Who in the hollow of His hand

Holds all the growth of all our land-

A nation's growth from sea to sea

Stirs in his heart who plants a tree.

(From Poems of H. C. Bunner)

Copyright, by Charles Scribner's Sons.

\section{THREE TREES}

(Arbor Day Recitation for Three Pupils.)

\section{By WHL AIKEN.}

First
Pupil:

Second

Pupil:

Third

Pupil:
One planted a tree of "Selfishness," Away from the sun's warm ray; He spread Conceit about the roots And watched it day by day-

A time it grew, yet flourished not, The food of life denied;

It struggled with a fool's desireThen drooped away and died.

One planted a tree of "Sweet Revenge," Nor reckoned he the end.

It swiftly grew and spread its shade, But only to offend.

None came to seek its shadows grim Save one, with Satan's air;

Its noisome shade at last brought deathTo him who planted there.

One planted a tree of "Happiness," And for its growth would pray;

He scattered Love about its roots And watched it day by day.

It slowly strong and noble grew, And myriads sought its shade;

It brought sweet peace to all who came-A tree that God had made. 


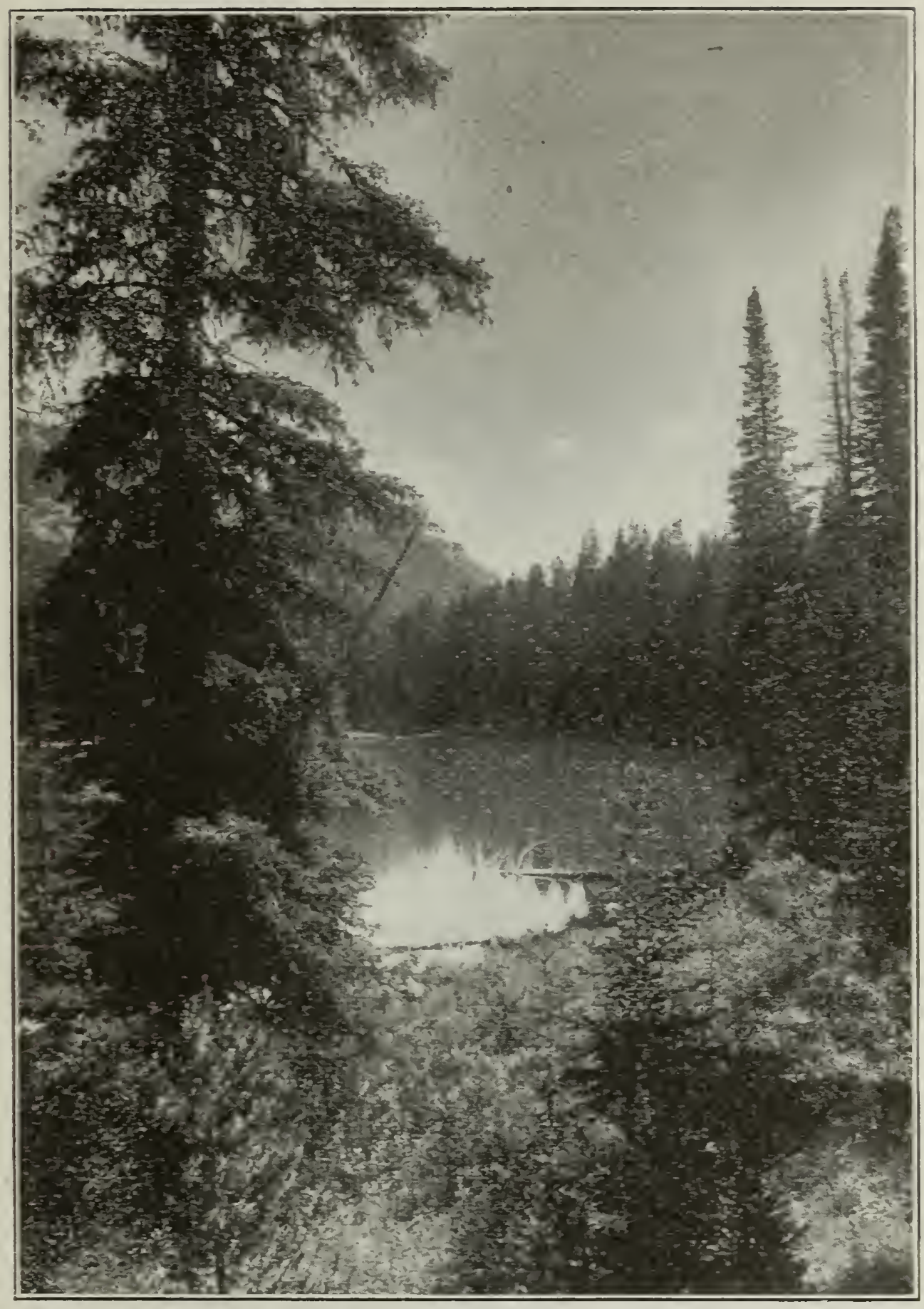

(Loaned by Department of Agriculture and Publicity) Ram's Horn Lake, Upper Gallatin

\section{HIAWATHA'S CANOE}

"Give me of your bark, O Birch Tree!

Lay aside your cloak, O Birch Tree!

Lay aside your white skin wrapper,

For the summer time is coming And the sun is warm in Heaven, And you need no white skin wrapper." And the tree with all its branches Rustled in the breeze of morning, Saying with a sigh of patience: "Take my cloak, O Hiawatha!" 
"Give me of your boughs, O Cedar!

My canoe to make more steady,

Make more strong and firm beneath me."

Thru the summit of the Cedar

Went a sound-a cry of horror,

But it whispered, bending downward,

"Take my boughs, O Hiawatha."

"Give me of your roots, O Tamarack!

Of your fibrous roots, O Larch Tree!

My canoe to bind together."

And the Larch with all its fibres,

Shivered in the air of morning,

Touched his forehead with his tassels,

Said with one long sigh of sorrow,

"Take them all, O Hiawatha."

"Give me of your balm, O Fir Tree!

Of your balm and of your resin,

So to close the seams together,

That the water may not enter

And the river may not enter."

And the Fir Tree, tall and sombre,

Answered wailing, answered weeping,

"Take my balm, O Hiawatha."

Thus the birch canoe was builded

In the valley by the river

And the forest life was in it

All its mystery and its magic,

All the lightness of the birch tree,

All the toughness of the Cedar,

All the Larch's supple sinews;

And it floated on the river

Like a yellow leaf in autumn

Like a yellow water lily.

\section{THE.DINKEY BIRD}

In an ocean way out yonder

(As all sapient people know),

Is the land of Wonder-Wander,

Whither children love to go;

It's the playing, romping, swinging,

That gives great joy to me

While the Dinkey-Bird is singing,

In the amfalula tree. 
There the gum drops grow like cherries,

And taffy's thick as peas-

Caramels you pick like berries

When and where and how you please;

Big red sugar-plums are clinging

To the cliffs beside the sea

Where the Dinkey-Bird is singing,

In the amfalula tree.

So when children shout and scamper

And make merry all the day,

When there's naught to put a damper

To the ardor of their play:

When I hear their laughter ringing,

T'hen I'm sure as sure can be

That the Dinkey-Bird is singing

In the amfalula tree.

For the Dinkey-Bird's bravuras

And staccatos are so sweet-

His roulades appoggiaturas,

And robustos so complete,

That the youth of every nation-

Be they near or far away-

Have especial delectation

In that gladsome roundelay.

Their eyes grow bright and brighter,

Their lungs begin to crow,

Their hearts get light and lighter,

And their cheeks are all aglow:

For an echo cometh bringing

The news to all and me,

That the Dinkey-Bird is singing

In the amfalula tree.

'I'm sure you like to go there

And see your feathered friends-

And so many goodies grow there

You would like to comprehend!

Speed, little dreams, you're winging

To that land across the sea

Where the Dinkey-Bird is singing

In the amfalula tree.

-Field.

-From "The Poems of Eugene Field," Published by Charles Scribner's Sons. 


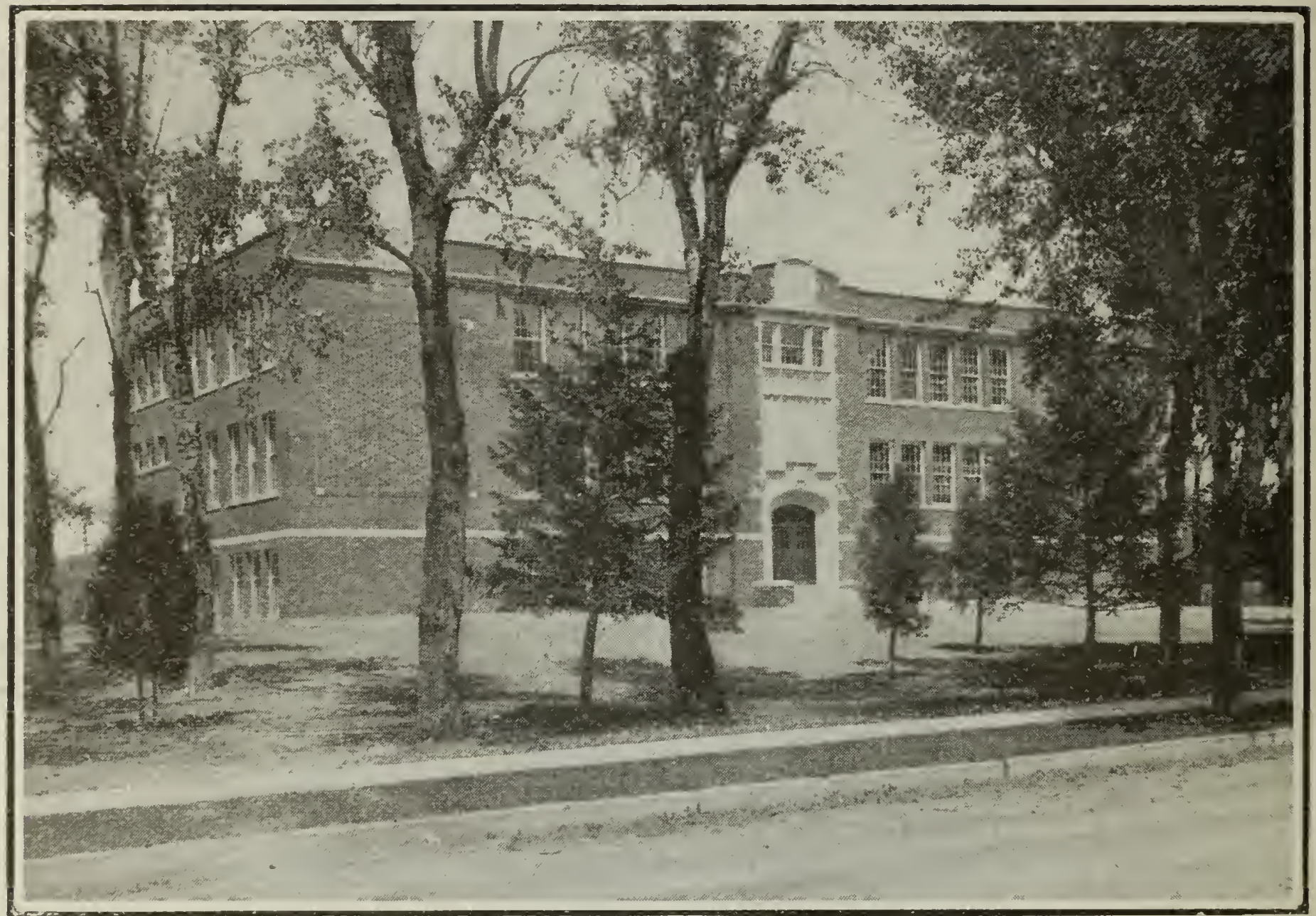

(Loaned by Department of Agriculture and Publicity) Powell County High School, Deer Lodge

\section{PLANT A TREE}

He who plants a tree

Plants a hope.

Rootlets up thru fibers blindly grope;

Leaves unfold into horizons free.

So man's life must climb

From the clods of time

Unto heavens sublime.

Canst thou prophesy, thou little tree,

What the glory of thy boughs shall be?

He who plants a tree

Plants a joy.

Plants a comfort that will never cloy-

Every day a fresh reality.

Beautiful and strong,

To whose shelter throng

Creatures blithe with song.

If thou couldst but know, thou happy tree.

Of the bliss that shall inhabit thee! 
He who plants a tree,

He plants peace.

Under its green curtains jargons cease;

Leaf and zephyr murmur soothingly;

Shadows, soft with sleep,

Down tired eyelids creep,

Balm of slumber deep.

Never hast thou dreamed, thou blessed tree,

Of the benediction thou shalt be.

He who plants a tree,

He plants youth:

Vigor won for centuries, in sooth;

Life of time, that hints eternity!

Boughs their strength uprear,

New shoots every year

On old growths appear.

Thou shalt teach the ages, sturdy tree, Youth of soul is immortality.

—Lucy Larcom.

\section{THE FOREST PLEADERS}

\section{(Arbor Day Recitation for Six Pupils.)}

\section{By E. T. Allen.}

First Pupil:

(carrying evergreen branch)

Second Pupil:

(carrying pail of water)

Third Pupil: (carrying pet animal

\section{AM THE FOREST.}

I clothe this western land

With beauty, and on every hand

You turn to me in daily need.

Your best friend I have always stood;

You could not live not using wood.

For your protection now I plead.

Nor do I bid you take my word;

Let these my witnesses be heard.

\section{AM THE STREAM.}

From my woodland springs

To river mouth where the white gull wings

Over the ships from the ends of the earth,

I flow to your homes and mills and fields,

And carry the freight that the harvest yields,

But shady forests gave me birth.

\section{AM THE WILD THINGS.}

I speak for graceful deer

And flashing trout in brooks, pools clear,

For singing birds and squirrels pert,

And all the wearers of feather and fur.

What should we do if no forest were

To shelter us from fear and hurt? 
Fourth Pupil:

(carrying ax)

Fifth Pupil

(carrying

fishing rod)

Sixth Pupil:

(strikes match and holds it burning)

All:

(FUTURE

blows match

out, watches as

he drops it, then

tramps it out)

\section{AM INDUSTRY.}

To me the forest brings

Reward for labor and all things

That money buys, for in this state

Over half our wage-earners' pay

Comes from lumbering in some way.

The fate of forests is my fate.

\section{AII PLEASURE.}

Happy vacation days,

Camping, hunting, and all the ways

of nature in her gladdest moods,

The forest holds for girls and boys

Who love outdoors and wholesome joys.

There is no playground like the woods.

\section{AM THE FUTURE.}

Shall all these pass away?

Must we look forward to a day

Of fire-charred, lifeless, streamless slopes

Where thoughtless match or unwatched brand

From Man's ungrateful, careless hand

Has destroyed his own children's hopes?

\section{FIRE IS OUR ENEMY.}

Won't you help us then?

Learn yourselves, and teach all men,

This the lesson all must learn:

Put ont the campfire and the match;

Careful with slash and clearing-patch;

Leave no fire in the woods te burn. 

